\title{
Inertial vs. mindful repetition of previous entry mode choices: do firms always learn from experience?
}

Article

Accepted Version

Creative Commons: Attribution-Noncommercial-No Derivative Works 4.0

Albertoni, F., Elia, S. and Piscitello, L. (2019) Inertial vs. mindful repetition of previous entry mode choices: do firms always learn from experience? Journal of Business Research, 103. pp. 530-546. ISSN 0148-2963 doi:

https://doi.org/10.1016/j.jbusres.2018.02.034 Available at https://centaur.reading.ac.uk/84136/

It is advisable to refer to the publisher's version if you intend to cite from the work. See Guidance on citing.

To link to this article DOI: http://dx.doi.org/10.1016/j.jbusres.2018.02.034

Publisher: Elsevier

All outputs in CentAUR are protected by Intellectual Property Rights law, including copyright law. Copyright and IPR is retained by the creators or other copyright holders. Terms and conditions for use of this material are defined in the End User Agreement.

www.reading.ac.uk/centaur 
Central Archive at the University of Reading

Reading's research outputs online 


\title{
WHEN DO OFFSHORING COMPANIES LEARN FROM THE REPETITION OF FORMER ENTRY MODES?
}

\begin{abstract}
Experience, meant as the repetition of the same action, is considered a predictor of the entry mode choice in foreign markets because it allows reducing uncertainty. However, repetition does not necessarily increase the expected performance, depending on the learning stemming from previous experiences. Focusing on offshoring decisions, namely the choice between captive and outsourcing entry mode, we distinguish between the inertial repetition of routines vs. the mindful repetition of previous entry modes (where the company distinguishes and internalizes the outcomes of the past offshoring initiatives associated to the entry choices). We claim that: (i) the latter leads to higher growth perspectives for the focal offshoring initiative, and; (ii) learning is higher when repetition concerns captive entry modes. Our empirical analysis, run on 410 companies' offshoring decisions undertaken from 2006 to 2011, confirms our expectation.
\end{abstract}

Keywords: Repeated entries; International experience; Offshoring; Outsourcing and captive entry modes. 


\section{INTRODUCTION}

The existence of transaction costs is one of the main explanations of the traditional make-orbuy dilemma in entry mode studies involving offshoring firms. Transaction Cost Economics (TCE) argues that, when transaction costs are high, companies tend to opt for wholly owned (i.e. captive) solutions rather than arms-length contracts with external suppliers (i.e. outsourcing) (Williamson, 1975). However, different theoretical lenses are required to understand how organizations identify over time the entry mode enabling their competitiveness, as long as the TCE approach does not include learning (Teece, 2014). Moreover, the capabilities leading to competitive advantages are better explained adopting a multidisciplinary and dynamic approach (Cantwell, 2014).

With reference to the entry mode choice in foreign markets, several contributions argue that previous experience is crucial to explain subsequent entries (Chan \& Makino, 2007; Chang, 1995; Chang \& Rosenzweig, 2001; Erramilli, 1991; Gao \& Pan, 2010; Guillen, 2003; Lu, 2002; Padmanabhan \& Cho, 1999; Swoboda, Elsner \& Olejnik, 2015). Indeed, experience allows companies to reduce the perceived environmental and transactional uncertainty (Anderson \& Gatignon, 1986; Aulakh, Kotabe \& Sahay, 1996; Benito \& Gripsrud, 1992). In particular, the literature has stressed the importance of country-specific experience, which reduces the perception of the institutional and cultural distance between the home and the host country (Benito \& Gripsrud, 1992; Henisz \& Macher, 2004; Kogut \& Singh, 1988; Tihanyi, Griffith, \& Russel, 2005; Johanson \& Vahlne, 1977), thus mitigating the liability of foreignness, i.e. the additional cost originating from limited knowledge of the host country (Gao \& Pan, 2010). However, the connection between country-specific experience and the reduction of the liability of foreignness has been probably over-emphasized; Luo and Peng (1999) argue that country-specific experience is especially important in the start-up phases of foreign operations as long as the effect of experience on performance tends to decrease. Moreover, the mere understanding of the host country does not guarantee lasting competitiveness (Delios \& Beamish, 2001; Luo \& Peng, 1999) and, by definition, country-specific experience can be employed only when investing in the same country. 
Experience can provide MNCs with more than the mere reduction of country-specific uncertainty. In particular, entry-specific experience, i.e. experience stemming from the repetition of the same type of entry mode, enables companies to strengthen and/or develop capabilities that are not necessarily country-specific and that can be adopted across different geographical areas. The literature identifies two different learning mechanisms that firms can take advantage of by repeating the entry mode choice (Di Gregorio, Musteen \& Thomas, 2009; Gao \& Pan, 2010), thus reducing uncertainty associated to liability of foreignness when investing abroad. On the one hand, repetition implies an experiential learning that strengthens the capability to set-up and manage the foreign venture, such as the ability to select, negotiate and monitor the external contractor or to organize the hierarchical and organizational architecture of the foreign subsidiaries. On the other hand, repetition can also trigger the development of new organizational knowledge, i.e. the acquisition of new routines that affect not only the management of the specific entry mode, but also the whole business model of the firm, through the transfer of the best practises from the subsidiaries and from the external suppliers to the headquarters and to the new foreign ventures.

However, we still have limited understanding of how and to what extent the repetition of previous entry mode can trigger these learning mechanisms and, ultimately, affect the outcomes of the new foreign ventures. In fact, authors studying the relationship between entry modes and outcome identify successful entries by looking at the fit between the chosen mode of entry and the predicted one (Aulakh, Kotabe \& Sahay, 1996; Brouthers, 2002; Castañer, Mulotte, Garrette \& Dussauge, 2013; Elia, Caniato, Luzzini \& Piscitello, 2014; Leiblein, Reuer \& Dalsace, 2002; Woodcock, Beamish \& Makino, 1994). According to these approaches, performance is expected to increase when the firm selects the entry mode that better fits the contingencies of the actual investment based on firm's resources, transaction characteristics and local context, while overlooking the role of previous experience. To bridge this gap, we study the relationships between different types of repetition of entry mode and growth perspective of the new foreign ventures. To this end, we distinguish between inertial vs. mindful repetition, and the contingent effect of specific entry modes (captive vs. outsourcing) on this main relationship. 
As regard the former, firms can repeat their previous choices ritualistically; the inertial selfimitation of previous choices is associated to learning from the process (Perkins, 2014), but it may also lead to lock-in effects, organizational inertia and -ultimately- problems of over-confidence and learning myopia (Petersen, Pedersen \& Lyles, 2008). We argue that this type of repetition leads to "inertial" learning ${ }^{1}$, where firms sticks to existing routines, thus neglecting the possibility to introduce new successful routines into the organization of the company (Levitt \& March, 1988). In other terms, although inertial repetition can still trigger the reduction of liability of foreignness and the experiential learning, it is likely to prevent from the exploration of new organizational knowledge and from the adaptation of existing knowledge to new circumstances (Lewin \& Massini, 2003; Lewin, Massini, \& Peeters, 2011; Nelson \& Winter, 1982).

By contrast, firms may identify the organizational best practices that are responsible for the past successful entry modes, and develop and adapt them to the new initiatives, as theorized by the dynamic capability approach (Teece, Pisano \& Shuen, 1997; Teece, 2014). This type of repetition leads to "mindful" learning (Weick \& Sutcliffe, 2006), and the growth perspective of the new foreign venture is likely to be higher than in the previous case (i.e. inertial approach).

Concerning contingencies, we consider captive vs. outsourcing entry mode, and claim that the repetition of a captive entry mode is associated to a more direct and effective transfer of information, experiential learning and organizational knowledge (Gao \& Pan, 2010), while outsourcing implies the involvement of an external company, which might be less interested in transferring information. Therefore, growth perspectives of the new foreign ventures are greater in case of repetition of captive than in case of repetition of outsourcing entry modes.

In order to test our conceptual framework, we develop an empirical analysis relying on 410 offshoring initiatives involving business functions undertaken from 2006 to 2011 . We distinguish between inertial and mindful repetition through a two-stage model, and find that: (i) only the latter affects positively the growth perspective of the focal offshoring initiative, and (ii) the effect of both mindful and inertial learning are larger in case of captive than in case of outsourcing entry mode

\footnotetext{
${ }^{1}$ Levinthal \& Rerup (2006) define this type of learning as "less mindful" or "routine" learning.
} 
Our findings add on the relationship between entry mode and experience along different lines. First, we show the relevance of previous entry-mode experience when firms choose between keeping in-house and outsourcing. Second, we disentangle different learning mechanisms associated to repetition. Additionally, we link entry choices to their future outcome by showing that mindful repetition of previous experiences leads to future higher growth perspectives than inertial repetition. Finally, we show that firms repeating captive entry mode are more likely to increase the growth perspectives of the new ventures with respect to firms repeating the outsourcing entry modes, meaning that the learning mechanisms triggered by the former are stronger than the learning mechanisms triggered by the latter.

The remainder of the paper is organized as follows. The second section illustrates the conceptual framework and, specifically, it discusses how inertial vs. mindful repetition lead to different growth perspectives, and distinguishes between repetition of outsourcing vs. repetition of captive mode. The third section presents the empirical analysis, the data and the models adopted. The fourth section illustrates the empirical results. Finally, the fifth section discusses our findings and concludes.

\section{CONCEPTUAL FRAMEWORK}

When facing new challenges, organizations usually rely on their former experience and often repeat their previous choices and behaviour. However, repetition of former experiences does not necessarily lead to higher performance (Argote \& Miron-Spektor, 2011) as replication of, and forgetful reliance on, previous routines might be associated to an "inertial" type of learning. For example, when Norwegian authorities had to operate a sea-based oilrig for the first time, they decided to rely on their experience on ship operations; unfortunately, the safety rules that existed for ships were not adequate and the rig collapsed (March \& Olsen, 1989). Individuals and organizations tend to 
normalize as acceptable deviations that fit within the pre-existing routines some circumstances that would instead deserve distinctive labels ${ }^{2}$ (Weick \& Sutcliffe, 2006).

Conversely, behaviours involving recombination do refer to a mindful type of learning (Argote, 2006). The concept of mindfulness was originally developed in the psychological literature and refers to the individuals' state of engagement in active information processing regarding their former experiences (Weick \& Sutcliffe, 2006). Similarly, in organizations, routines evolve through a process of encoding of outcomes (Levinthal \& Rerup, 2006). Indeed, the routines developed in former experiences cannot be replicated as such. It is required a reflection on the differences and the similarities between past and present cases in order to adapt the existing knowledge to new projects as "the encoding of outcomes, as perceived to be successful or not, is critical to the evolution of routines" (Levinthal \& Rerup, 2006: 504).

We adopt this framework to distinguish inertial vs. mindful repetition of previous entry mode choices by companies entering a foreign market.

\section{The learning mechanisms underlying the entry-mode repetition}

Repetition of the entry mode can benefit the growth perspective of a new foreign venture reducing uncertainty and, therefore, liability of foreignness. Indeed, repetition allows firms to gain specific knowledge on how to enter and operate in foreign markets by acquiring first-hand experience from ongoing operations (Gao \& Pan, 2010). The repetition of the entry mode, either captive or outsourcing, enables the firm to identify the wide range of aspects that need to be taken into account when operating in foreign locations, thus reducing the level of uncertainty. Indeed, firms that have already adopted a captive entry mode can rely on the network of foreign subsidiaries to gain knowledge about international markets and business opportunities. At the same time, companies repeating outsourcing investments can glean important insights and knowledge about foreign markets thanks to the intensive interactions, personal meetings and frequent communications with the service providers, which typically characterize both the pre- and the post-implementation phases of each

\footnotetext{
${ }^{2}$ The same behaviour has been investigated at the individual level (e.g. Gersick \& Hackman, 1990).
} 
previous agreement (Di Gregorio et al., 2009). In both cases, the result is the reduction of the uncertainty associated to international investments and an increase of the alertness to international business opportunities, which translate into a decrease of the liability of foreignness. Additionally, previous entry mode can also act as a bridge to a broader network of foreign contacts, such as customers and suppliers, which might accelerate the speed to market (Murtha, 2004) and reduce the liability of outsidership (Johanson \& Vahlne, 2009). As a consequence, firms can employ this knowledge to improve and to accelerate the set-up of the present offshoring initiative and to foster its future growth perspective.

Repetition allows experiential learning as firms face lower operation difficulties in setting up and managing the present foreign initiative by repeating the same entry mode already experienced before (Chang, 1995; Delios \& Beamish, 2001; Gao, Pan, Lu, \& Tao, 2008). Repeated outsourcing enables the firm to develop non supplier-specific routines that decrease uncertainty and accelerate processes, thus reducing transaction costs and improving trust (Aulakh, Kotabe \& Sahay, 1996). A procedure to identify the proper supplier, to negotiate the agreement and to monitor its activity, for instance, can be replicated across different outsourcing initiatives involving other suppliers located in different countries (Di Gregorio et al., 2009). At the same time, a company might rely on a specific contractual form containing standard clauses (e.g. property right specifications, service level agreements etc.) that have been developed by building upon previous outsourcing experience and that are applied to every new supplier (with some degrees of adaptation). Benefits in terms of experiential learning can arise also from the repetition of captive initiatives. Indeed, wholly owned subsidiaries imply the delegation of the control of firm's assets to the management; thus, repetition allows firms to strengthen their capabilities to develop control mechanisms to align managers and owners' as well as headquarters and subsidiaries' objectives, and to design organizational and hierarchical architectures that are more efficient and effective in pursuing this goal. Hence, the gains from experience can reduce managerial uncertainty in the organization of both captive and outsourced initiatives abroad, thus increasing the probability to foster the growth perspectives of the new initiative.

Repetition also allows firms to gain knowledge that is not only specific to setting-up and managing the new foreign venture, but that involves the organization and the management of their 
whole business. The intense exchange of information and the frequent interaction with the foreign subsidiary (in case of captive entry mode) and with the service provider (in case of outsourcing) provides the firm with the opportunity to absorb and integrate tacit knowledge, best practices and successful business models in their organization (Nonaka, 1994; Di Gregorio et al., 2009). Hence, firms can develop new capabilities by converting and amplifying at organizational-level the tacit knowledge arising from human interactions. Since knowledge represents the main source of a firm's competitive advantage (Nonaka \& Takeuchi, 1995), this is likely to translate into an increase of the growth perspectives of the present and future initiatives. This holds true especially in international businesses, which offer the opportunity to source and combine the knowledge and the best practises from different markets (Di Gregorio, et al., 2008). For instance, after opening its subsidiary in South Korea, Wal-Mart discovered that multi-floor shops boost the sales more than single-floor shops, since customers used to spend more time inside the building. Hence, they decided to adopt the same type of strategy when opening new shops in other countries, in order to foster the growth perspectives of the new foreign initiatives (Hill, 2011). Another U.S. company used to outsource to a Korean representative the marketing of its software systems. After a request from the Korean partner, the U.S. company accepted to let the supplier not only sell but also manufacture the workstations (based on the U.S. company's components) and provide the after-sales services. This arrangement enabled the Korean partner to develop new capabilities and to offer more customized solution, and the US client to adopt a new business model, which allowed to sell more tailored products and to get rid of lowermargin installation activities (Di Greogorio et al, 2009). Previous foreign ventures represent an extraordinary opportunity to spiral the knowledge created by subsidiaries and suppliers into new organizational knowledge, thus fostering the international competitiveness of the new ventures.

\section{Inertial vs. Mindful Repetition in Firms' Entry Mode Decision}

Although repetition of previous actions can trigger the learning mechanisms discussed in the previous paragraph, we argue that inertial repetition can partially inhibit the resulting positive effects. Initiatives abroad are very costly in organizational terms, and the sunk costs tackled in past foreign ventures lead decision makers to be reluctant to switch to different solutions thus leading to lock-in 
effects to previous entry choices (Mudambi, 1998). The risk of this behaviour is that firms cease to acquire knowledge from outside and merely commit and paralyze to existing routines, thus fostering organizational inertia (Cohen \& Levinthal, 1990; March, 1991; Vermeulen \& Barkema, 2001). Inertial repetition is likely to limit some of the potential benefits arising from previous experience, since, as suggested by Hutzschenreuter, Pedersen, and Volberda, (2007: 1057) interpreting the internationalization process model (Johanson \& Vahlne, 1977), "the gradual accumulation of experience is both the limiting and the driving factor of internationalization". The inertial selfimitation of established routines reduces the uncertainty and the operational difficulties related with international expansion through the experiential learning, but it also leads to problems of overconfidence concerning the existing routines and learning myopia, which are likely to limit the development of organizational knowledge and innovation (Petersen et al., 2008).

By contrast, when firms adopt a mindful repetition, they employ the experience gained in the past to further develop their skills and support the growth perspectives of the new foreign ventures. That happens when companies adapt their organizational and managerial capabilities from the past to the present context. This perspective relies on the assumption that the ownership of knowledge is not sufficient per se to foster performance, requiring to be complemented with a proactive process of capability building where firms re-process the knowledge and apply it to the new contexts (Tallman, 2003; Teece, 2014). Firms replicating the entry mode after discerning the outcome of previous foreign ventures are able to acquire the knowledge and information regarding the routines that are responsible for success and failures of past initiatives across different functions and countries. The knowledge acquired is then employed by the firm to identify the most promising investment projects and select the organizational routines enabling the success of the new entry. Finally, after selecting the project, the company fits and adapts its existing knowledge to the purposes of the new venture, thus replicating former entries.

The internationalization of Wal-Mart provides an interesting example of how this company adopted a mindful learning approach, by improving and adapting progressively its business model when repeating the (captive) entry mode. Wal-Mart learnt not only from its successes, as in the case of the Korean multi-floor shops, but also from its failures. After opening the first shop in Mexico, 
Wal-Mart realized that it was no possible to replicate the U.S. business model, which was based on a very efficient logistics, a strong bargaining power with the suppliers, and the marketing of products complying with the tastes of the U.S. costumers. Indeed, the Mexican logistics and infrastructures were not as developed as in the U.S.; additionally, Mexican suppliers were not willing to grant discounts due to the underdeveloped distribution network of Wal-Mart shops in Mexico; finally, Mexican tastes were very different from the U.S. tastes. After that experience, Wal-Mart changed and adapted its business model when opening new shops in foreign countries, by establishing strategic partnership with logistics companies and local suppliers in the host countries, and by adapting the products to the local tastes (Hill, 2011). Therefore, the mindful repetition of the entry mode, based on the identification of past successes and failures, is probably one of the key factors underlying the successful internationalization of Wal-Mart, which was able to foster the growth perspective of its new ventures by exploiting the creation of new organizational learning from past experiences.

A mindful learning can, hence, become a self-generating process where firms that have learnt how to gain from previous successes and failures will continue to do so at an increasing rate (Cohen \& Levinthal, 1990), and the growth of the present and future initiative is fostered by the incremental improvement of managerial and organizational capabilities (Chang, 1995). This means that the mindful repetition of the entry mode is expected to enhance the growth perspective of the present initiative more than the inertial repetition. Therefore, we expect the following first hypothesis to hold:

Hypothesis 1: A mindful repetition of the entry mode choice increases the growth perspective of the present offshoring initiative more than an inertial repetition of the entry mode choice.

\section{Captive vs. Outsourcing Repetition in Firms' Entry Mode Decision}

So far, we discussed about the mechanisms underlying the inertial and mindful repetition of captive vs. outsourcing initiatives. We now stress such peculiarities by claiming that these two different entry modes can affect the extent to which the learning mechanisms underlying inertial and mindful repetition benefit the growth perspective of the focal venture. 
According to TCE, outsourcing solutions involve two or more firms, and the management and control of activities require coordination and consensus among partner organizations, but solutions are typically associated to a lower resource and operational involvement than in hierarchical modes. The latter, instead, are managed and controlled by a single entity, entail higher commitment, tighter control and larger risks, but eliminate the need to gain cooperation and consensus from other firms (Brouthers and Brouthers, 2003). This implies that firms adopting a captive entry mode are more likely to acquire intensive and direct information flows, and to leverage their own learning-bydoing and task-specific experience in subsequent entries (Pan \& Tse, 2000; Foss \& Pedersen, 2002). Firms repeating a captive entry mode can nurture a process of learning by leveraging their network of subsidiaries, which can transfer both their knowledge about foreign markets and their best organizational practises directly to the headquarters and to the other subsidiaries through intranet platforms, frequent meetings, job turnover etc. Additionally, hierarchical and managerial fiat can be easily implemented to foster the full adaptation of the new practises within the company and, above all, in the new foreign venture, thus maximizing the effects of the acquired learning (Larsen \& Lyngsie, 2017).

Conversely, the involvement of external companies make the transfer of knowledge in outsourcing initiatives less immediate and less straightforward (Gao \& Pan, 2010). As such, the learning mechanisms discussed above (related both to the strengthening of existing capabilities, and to the development of new capabilities) are likely to be less effective when repeating an outsourcing than when repeating a captive entry mode. The supplier of an outsourcing initiative, for instance, might provide no useful information about how to operate in foreign markets, thus reducing the effectiveness of the learning mechanisms that decrease the liability of foreignness. Additionally, the contribution of experiential learning might be weaker in case of outsourcing than in case of captive experience due to the continuous change of partner, which requires a higher level of adaptation to the specific agreement and, hence, a lower possibility to reuse the past knowledge. Finally, the supplier might be reluctant to transfer its knowledge and best practices to the partner; at the same time, the client might have not sufficient absorptive capacities to learn from the external company. As a consequence, also the organizational-level learning mechanism might be less effective in case of 
outsourcing than in case of captive entry modes. Of course, outsourcing partners might engage in a long-term relationship based on detailed contracts specifying all the obligations and rights aiming at reducing all these incidents (Larsen \& Lyngsie, 2017), given that "a long-term contract that specifies the terms and conditions for some set of future transactions ex-ante, provides a vehicle for guarding against ex-post performance problems" (Joskow, 1987: 169). However, this approach is likely to increase the initial transaction costs, thus reducing the short-term profitability of the new foreign venture. Additionally, due to the high intangibility and specificity of knowledge, it is difficult to define extensive agreements and to design complete contracts, meaning that ex-post problems problems affecting the growth perspective might arise. Following this reasoning, we formulate our second hypothesis as follows:

Hypothesis 2: The inertial and the mindful repetition of the entry-mode choice have a more positive effect on the growth perspective of the present offshoring initiative when repeating a captive entry-mode than when repeating an outsourcing entry-mode.

\section{EMPIRICAL STUDY}

\subsection{The Context and the Sample}

To test our conceptual framework, we use the context of business functions offshoring. The offshoring phenomenon typically regards manufacturing and production activities delocalized to emerging economies (either through captive or through outsourcing entry modes) in order to exploit cost advantages, as long as knowledge-intensive activities are traditionally located in advanced countries' headquarters (Contractor, Kumar, Kundu, \& Pedersen, 2010). However, the standardization of complex tasks, the improvement of the capabilities in emerging economies and the advances in ICT have led to increasingly offshore to developing countries also high value-added business functions such as engineering services, product development and R\&D (Lewin, Massini, \& Peeters, 2009; Manning, Massini, \& Lewin, 2008). The underlying drivers are shifting accordingly from cost 
reduction to strategic resource achievement, meaning that firms need to source knowledge from abroad in order to improve their competitiveness. Therefore, the analysis of the relationship between entry-specific experience and outcome becomes extremely relevant for business functions offshoring, since firms are involved in sequential investments that require an increase of organizational capabilities through a process of knowledge recombination across different offshoring initiatives.

We employ the dataset developed by the Offshoring Research Network (ORN) survey, which inquires the offshoring of business functions including knowledge intensive activities (e.g. engineering services, product development and R\&D). This is one of the most comprehensive initiative for studying offshoring of business services by companies of varied size, in a wide range of industries and countries (Elia et al., 2014; Lewin \& Peeters, 2006; Lewin et al., 2009).

ORN initiated thanks to the Centre for International Business Education and Research (CIBER) of Duke University in the United States, with the participation of an international network of researchers and practitioners counting 13 partner universities and business schools belonging to the following countries: Australia, Belgium, Brazil, China, Denmark, Germany, France, Italy, Japan, Korea, the Netherlands, the United Kingdom, and Spain. Each partner collected data on offshoring of business functions administrative services in their own country and shared them with the other members of the network, thus contributing to the ORN database.

The ORN program tracked global sourcing strategies, drivers, geographic dynamics, risks, entry mode, performance and plans across all industries and business functions through a detailed questionnaire about administrative and technical work from abroad. The respondents to the ORN survey are managers of the companies that implemented the offshoring initiatives. The survey was sent to a top manager (e.g. CEO, CFO, etc.) of listed companies by email with the request to pass it to colleagues with expert information about offshoring initiatives and reshoring plans of his/her company. The ORN database builds on six repeated surveys starting in 2005; the last survey was administered in 2011.

This dataset benefits from including a remarkably high number of home countries, which reflects the geographic areas covered by ORN partners, whose headquarters are mostly located in the European and US areas. The offshoring flows are directed towards advanced, emerging and 
developing countries. The original ORN project was designed to study the offshoring phenomenon using an original comprehensive survey, which covered most aspects of the offshoring of business services at the level of the individual implementation. Therefore, despite some limitations related to the unavailability of panel data, we find that the ORN dataset is a valuable source to study the repetition of the entry modes of offshoring companies given that, for each firm, we are able to assess the sequence of the offshoring initiatives having the information about the year of implementation for each venture.

In order to include some factors related to the role of the macro-economic performance, the institutions and the culture of the host country, we integrated the ORN database with other three datasets: (i) the World Competitiveness Yearbook; (ii) the World Bank, and (iii) Hofstede (2001) The latest release of the ORN dataset issued in 2011 records 5,619 observations; however, as we focus on the offshoring initiatives with previous experiences, the number of observations in our econometric investigation amounts to 410 (belonging to 138 companies), also due to missing values in some of the variables considered. More than $66 \%$ of the firms have their headquarters in the United States and Canada; the rest of the firms have their headquarters in Europe or Australia (table 1). The host country with the highest percentage of offshoring initiatives is India (around 34\%, table 2). Regarding business functions, the ones with highest percentage of offshoring ventures are the Customer Contact and the Information Technology (both with a percentage of around 18\%, table 3). The software and IT service is the industry with the highest percentage of offshoring initiatives with a percentage of almost $26 \%$ (table 3 ).

- Insert table 1, 2 and 3 about here -

\subsection{Methodology}

\footnotetext{
${ }^{3}$ The combination of the ORN survey with external databases is also useful to limit the Common Method bias.
} 
The literature has already shown that the relationship between entry mode and outcome can be potentially affected by self-selection and endogeneity problems resulting from underlying omitted and unobserved factors influencing both strategy choice and performance. Indeed, managers typically select the entry mode of a foreign venture having a specific outcome in mind, meaning that, on the one hand, the ultimate outcome is conditional upon unobserved factors that influence firms' modes of entry; on the other hand, the entry mode turns out to be affected by the expected outcome. As long as statistical analyses not accounting self-selection process can suffer from biased estimations, we adopted a two-step selection approach à la Heckman (1979). This technique is probably the most established methodology in the literature when assessing the relationship between the entry mode and an outcome variable and which enables to obtain consistent and unbiased estimates (Brouthers, 2002; Castañer et al., 2013; Elia et al., 2014; Leiblein et al., 2002; Shaver, 1998) $)^{4}$. Specifically, in the first stages, we estimate a probit model in which the entry mode (outsourcing versus captive) is the dependent variable, and it is regressed against a set of variables identified in the literature.

Accordingly, in step (1) we assess the relationship between the entry mode and a set of variables, including the repetition of previous entry modes:

$$
\text { Entry mode }=f \text { (repetition of previous entry modes, } \text { controls, } \varepsilon \text { ) }
$$

We then compute the entry-fit, i.e. the fit between the entry mode predicted by step (1) and the entry mode selected by the companies in our samples for each offshoring initiative. The entry-fit allows assessing the extent to which the entry choice of each foreign venture is based on a model driven by the repetition of previous entry modes. In step (2), we include the entry-fit as a main explicative variable, in order to investigate whether and how the outcome of the focal offshoring initiative is affected by an entry choice based on repetition:

\footnotetext{
${ }^{4}$ An instrumental variable approach controlling for the endogeneity underlying the entry mode choice could also be employed as alternative technique. However, in order to account also for the self-selection bias, we opted for a two-stage approach à la Heckman, which, indeed, is the most popular methodology employed in this literature.
} 


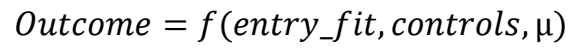

To test our conceptual framework, we run the two-step methodology twice. Indeed, through the first step we estimated two alternative models: (a) an "inertial entry choice model", i.e. an entry model based on the inertial repetition of past entry modes; (b) a "mindful entry choice model", i.e. an entry model based on the mindful repetition of past entry modes. The inertial repetition of past entry modes has been captured by assessing the impact on the actual entry mode (e.g. outsourcing) arising from the former entries of the same type (i.e. outsourcing) and from the former entries of the opposite type (i.e. captive). We consider as an evidence of inertial repetition when, in the first step of model (a), the outsourcing (captive) entry mode is fostered by the past outsourcing (captive) offshoring initiatives, regardless of their past performance.

The mindful repetition of past entry modes is still assessed as the impact on the actual entry mode arising from the entries of the same vs. opposite type, but after distinguishing between the growing versus the non-growing initiatives. We consider as an evidence of mindful repetition when, in the first step of model (b), the outsourcing (captive) entry mode is fostered by the past successful outsourcing (captive) offshoring initiatives. Indeed, the literature has shown that organizational learning is measured through changes in the characteristics of performance (Argote \& Epple, 1990; Dutton \& Thomas, 1984), and that knowledge and learning translates into greater growth perspectives and further investments. This means that past growing outsourcing (captive) experiences are the result of a process of mindful learning, and that the latter can trigger a mindful entry choice model as long as it is able to positively affect the probability to undertake an outsourcing (captive) entry mode in the first step.

In this way, we are able to distinguish between the inertial entry choice model, where former initiatives are ritualistically iterated without considering the former outcome, and the mindful entry choice model, where former initiatives are iterated once allowed for the former outcome. Specifically, in step (1), equations (1.a) estimates the inertial entry choice model (a), while equation (1.b) concerns the alternative mindful entry choice model (b): 
Accordingly, two entry-fits have been estimated and two different equations have been employed also in step 2. Specifically, equation (2.a) investigates the impact of the entry fit arising from equation (1.a), i.e. the inertial entry fit, while equation (2.b) considers the entry fit arising from equation (1.b), i.e. the mindful entry fit:

$$
\text { Outcome }=f\left(\text { inertial entry fit, controls }, \mu_{1}\right)
$$

$$
\text { Outcome }=f\left(\text { mindful entry fit, controls, } \mu_{2}\right)
$$

The inertial entry fit captures the extent to which each offshoring initiative complies with the inertial entry choice model (a), and equation 2.a how this affects the outcome of the present offshoring initiative. Conversely, the captive entry fit captures the extent to which each offshoring initiative complies with the mindful entry choice model (b), and equation 2.b how this affects the outcome of the present offshoring initiative ${ }^{5}$. Figure 1 provides a representation of the empirical methodology employed in our paper.

- Insert figure 1 about here -

In the next paragraphs we illustrate in details the dependent, explanatory and control variables employed in the two equations of each step.

\footnotetext{
${ }^{5}$ It is worth noting that the variable Outcome employed as dependent variable in step 2 refers to the current initiative, while the variable Outcome employed in equation 1.b refers to the former experiences. Additionally, the variable Outcome has not been employed directly in equation 1.b but only to distinguish between growing and not growing initiatives. Of course, we are aware that using lagged value variables can only alleviate the endogeneity issue but it may not solve it completely.
} 


\subsection{Variables of Step (1)}

Dependent variable. The dependent variable in both equation (1.a) and (1.b) is the entry mode, i.e. a dummy (Outsourcing) which assumes value 1 for outsourcing (i.e. international, local or domestic third-party service provider), and 0 for captive (i.e. wholly-owned subsidiary). The variable is obtained from the following question in the ORN survey: "What is the service delivery model currently used for this offshoring implementation?". The number of captive $(51.46 \%$ of the sample with 211 observations) and outsourcing (48.54\% of the sample with 199 observations) initiatives is quite balanced.

Explanatory variables. The main explanatory variables employed in the equations of step (1) refer to the repetition of previous entry modes, which relies on the count of the times the two alternative types of entry modes have been already adopted by the company (Chan \& Makino, 2007; Chang, 1995; Dikova \& Van Witteloostuijn, 2007; Gao \& Pan, 2010; Guillen, 2003; Lu, 2002).

Specifically, in order to proxy the inertial repetition of previous entry modes, we define Repeated Captive Experience and Repeated Outsourcing Experience as the number of previous captive and outsourcing initiatives, respectively.

Likewise, to account for the mindful repetition of previous entry modes, we distinguished between Repeated Growing Captive Experience, Repeated Growing Outsourcing Experience, Repeated Non-Growing Captive Experience and Repeated Non-Growing Outsourcing Experience. The first two variables refer to the number of previous captive and outsourcing initiatives for which the respondent to the ORN questionnaire is expecting some growth perspectives, while the latter refer to previous captive and outsourcing experiences for which no growth is expected. Specifically, we counted the number of past captive and outsourcing experiences that were and were not planned to be expanded in the next three years, based on the answer to the question: "What are the plans for this implementation for the next three years? Expand the activities in the current offshore location: yes or no?". When the answer is "yes", we consider it as a growing experience, when the answer is "no", we 
consider it as a non-growing experience. Hence, these variables introduce in the count of previous offshoring ventures an assessment of their outcome, thus reflecting a mindful attitude in the replication of previous entry modes.

Table 4 provides an example of the procedure employed to build the explicative variables of equations 1.a and 1.b.

- Insert table 4 about here -

\section{Control variables}

We introduce Country-specific experience as a first control, in order to wipe off the countryspecific effect (i.e. the effect arising from the repetition of the investment in the same host country) from the entry-specific experience. This variable accounts for the number of times the company has already invested in the host country during past offshoring initiatives. In our sample, $46.5 \%$ of deals involve firms with no previous country-specific experience, while the remaining deals have a number of previous investments in the same country ranging from 1 ( $28 \%$ of the sample) to 7 ( $0.73 \%$ of the sample).

As regards the other controls, the literature suggests that offshoring is a complex phenomenon, which needs to be investigated at different levels of analysis (Hätönen \& Eriksson, 2009; Oshri, Kotlarsky \& Willcocks, 2015). Therefore, we introduced firm-level, function-level, industry-level, country-level and deal-level control variables that are likely to affect the entry mode of the foreign offshoring ventures. We employ the same controls in equations (1.a) and (1.b).

As regards the firm-level variables, we adopted a discrete measure of firms' size as long as ORN questionnaires collected categorical instead of continuous data: the dummy variable Small Firms (less than 500 employees) is the default, while the other two dummy variables account for Medium Firms (between 500 and 20,000 employees), and Large Firms (those with more than 20,000 employees). Small Firms account for 21.95\% in our sample, Medium Firms for $36.59 \%$ and Large Firms for $41.46 \%$. It is worth noting that the firms included in the ORN survey are quite large and this is the reason why the thresholds set for our size dummies are equally large. 
We then control for the functions and the industries. Specifically, we introduce a dummy variable, named High Value Added Functions, which distinguishes between high value-added activities (Product Design, Engineering Services and Research \& Development) and the remaining ones (Software Development, Call Centres, Finance and Accounting, Human Resources, Information Technology, Knowledge Services, Legal Services, Marketing and Sales and Procurement) ${ }^{6}$. Also, a standard industry control is included through a dummy variable named IT Sector, in order to account for the numerous ICT firms in the sample that have offshored especially in India, one of the top destinations for ICT industry due the large availability of service providers and skilled human resources (Pereira \& Malik, 2015).

As regards the country-level variables, we first control for the Cultural Distance between the home and host country involved in each deal, by employing the formula suggested by Kogut and Singh (1988), and based on Hofstede (2001) items ${ }^{7}$. Higher cultural distance is associated to higher uncertainty, which, on the one hand, might discourage a full commitment thus favouring an outsourcing solution but, on the other hand, it also implies higher transaction costs and, hence, a larger probability to select a captive entry mode. We also control for the institutional context and macro-economic performance of the host countries, which have been suggested to play a crucial role in the offshoring decisions by affecting the quality of resources, knowledge, skills and talent (Peng, Sun, Pinkham, \& Chen, 2009), through the variables Governance Infrastructure and Market Attractiveness, respectively (Globerman \& Shapiro, 2003). Both these variables are the result of a factor analysis implemented respectively on World Governance Indicators databases (source: World Bank) and the World Competitiveness Yearbook using only the average of the data between 2004 and 2011 (the years of the survey). Table 5 provides further details regarding the construction of these variables and the underlying items. Additionally, we accounted for firms having the US as home

\footnotetext{
${ }^{6}$ This variable has been built following Youngdahl, Ramaswamy, \& Dash (2010).

7 The items included in the measure of cultural distance are the followings (Hofstede, 2001): Power Distance Index (PDI), Individualism versus Collectivism (IDV), Masculinity versus Femininity (MAS), Uncertainty Avoidance Index (UAI), Long Term Orientation versus Short Term Normative Orientation (LTO), and Indulgence versus Restraint (IND).
} 
country by employing a dummy variable named Home country United States, as long as the majority of the firms in the sample belong to this country.

- Insert table 5 about here -

Finally, deal-level controls have been included by looking at the strategic drivers of each investment through the variables Access to Qualified Talents, Labour Cost, Colocation of Manufacturing and Market Penetration, which are based on a 1 to 5 Likert scale (source: ORN survey). The first two variables enable to understand if the deal is driven by resource-seeking or costsaving purposes, respectively, while the third one signals if the investment is connected with other investments already implemented in the area and the fourth one captures if the venture has been implemented to penetrate new markets abroad. These variables enable us to better account for the complex nexus between locations, motivations and disintegration arising from offshoring, which have been highlighted to be crucial to understand the offshoring phenomenon by several scholars (Hätönen \& Eriksson, 2009; Oshri, Kotlarsky \& Willcocks, 2015). Moreover, we account for the duration of each offshoring venture using the variable Age of the Initiative, computed as the difference between the year of the survey (i.e. 2011) and the year of the implementation of the deal.

\subsection{Variables of Step (2)}

Dependent variable. Growth Perspective is the dependent variable of both equations (2.a) and (2.b); it is measured as the company's intention to increment the activities at the current offshore location in the next three years (the relevant question in the ORN survey is: "What are the plans for this implementation for the next three years? Expand the activities in the current offshore location: yes or no?"). The variable assumes value 1 when it is forecasted an expansion of the offshoring venture, and 0 otherwise. The number of initiatives with growing perspectives in our sample is $234(57.07 \%)$.

It is worth noting that our dependent variable is a perceptual measure. Subjective measures have been largely employed as non-financial performance (Brouthers, 2002), also in studies about 
offshoring ventures (Hult et al., 2008; Martin, 2013). Even if subjective indicators suffer of social desirability bias, as long as respondents to surveys tend to reply in a manner that will be viewed favourably by other people, the adoption of financial data to assess firm's performance might be biased by short-run contingencies. Furthermore, some major issues challenge the adoption of objective performance measures in international business. Indeed, (i) companies are reluctant to provide objective data regarding their foreign subsidiaries; (ii) some offshoring ventures are not undertaken in order to obtain financial gains; (iii) it is not easy to convert data stemming from several countries and companies into a common and consistent unit of measure. Additionally, the relevance of the growth perspective as a key variable capturing the performance was remarked by Kaplan and Norton $(2001)^{8}$. The authors state that financial measures are not sufficient to assess the performance of a firm, due to the reasons explained above. Therefore, they propose a "Balanced Scorecard" methodology, which relies on interviews and discussions with senior executives and which is based on the evaluation of four different dimensions, including the "learning and growth perspectives". This relationship, which represents the core of our paper, is considered the most important dimension of the performance assessment, being the foundation of any strategy, since "in the learning and growth perspective, managers define the employee capabilities and skills, technology, and corporate climate needed to support a strategy" (Kaplan \& Norton, 2001, p.94).

Explanatory Variables. Following previous studies (e.g. Leiblein et al., 2002), we computed from both equations of step (1) the entry-fit between the predicted entry mode and the entry mode selected by companies as a continuous variable (ranging from 0 to 1 ), equal to $\Phi$ in case of outsourcing and to $1-\Phi$ in case of captive, where $\Phi$ is defined as the standard normal cumulative distribution function, as follows:

$$
\operatorname{Prob}(\mathrm{Yi}=1)=\Phi\left(\beta^{\prime} \mathrm{Xi}\right)
$$

\footnotetext{
${ }^{8}$ The paper by Kaplan and Norton (2001) was published in the journal "Accounting Horizons", which is part of the American Accounting Association.
} 
We named Inertial Entry Fit the entry-fit computed from equation (1.a) and Mindful Entry Fit the entry-fit computed from equation (1.b). The main advantage of computing two entry fits is that they allow identifying and distinguishing effectively the offshoring initiatives based on an inertial entry choice model and the offshoring initiatives based on a mindful entry choice model. The inertial and mindful entry fits have been introduced as main independent variables in equations (2.a) and (2.b), respectively9 . According with hypothesis 1, we expect Mindful Entry Fit to have a stronger impact on growth perspective than Inertial Entry Fit.

Following the literature assessing the relationship between entry mode and performance (Brouthers, 2002; Castañer et al., 2013; Elia et al., 2014; Leiblein et al., 2002; Shaver, 1998), we also introduced the dependent variables of step (1), i.e. Outsourcing, as explicative variable of step (2). This variable enables to investigate whether the entry mode (beside the entry-fit) has both a direct impact on the growth perspective and a moderating effect on the inertial and mindful entry fits. In order to test the latter, we adopted two alternative methods. On the one hand, we introduced the interaction term between outsourcing and inertial entry fit in equations $2 . a$ and between outsourcing and mindful entry fit in equation 2.b. On the other hand, following the recommendation by Greene (2010) and Gooris and Peeters $(2016)^{10}$ and following the literature on entry modes and performance (see, e.g. Leiblein et al., 2002), we also split equations 2.a and 2.b in two subsamples, one accounting for outsourcing and one accounting for captive initiatives. Based on hypothesis 2 , we expect a negative moderation effect of outsourcing on both entry fits (when using the interaction term) and a stronger positive effect of inertial and mindful entry fit in case of captive than in case of outsourcing initiatives (when using subsamples).

\footnotetext{
${ }^{9}$ It is worth noting that using two separate equations not only enables us to estimate two alternative repetition entry choice models, i.e. the inertial (a) and the mindful (b) ones, but also to avoid multicollinearity problems both in the first and in the second step. Indeed, the explicative variables employed in equation 1.a, which distinguishes between previous captive and previous outsourcing entry modes, are linear combination of the variables employed in equation 1.b, where each captive and outsourcing initiative is further sliced into growing and not growing initiatives. At the same time, running only once the second step would imply to use two different entry fits, i.e. the inertial and the mindful one, in the same equation, which is likely to give birth to a further multicollinearity problem, given that the entry fits are computed from two models whose key variables are linearly dependent one from each other.

${ }^{10}$ Greene (2010) suggests that the estimation technique based on interaction in non-linear models is "generally uninformative and sometimes contradictory and misleading". Therefore, he recommends dealing with interaction effects through model design (which, as in Gooris and Peeters, 2016, can be addressed through the use of subsamples) rather than employing interaction coefficients.
} 
Control variables. We employed in both equations of step (2) the same control variable of step $(1)^{11}$. The table in the appendix provides further information regarding all the variables adopted and their construction.

Table 6 provides the correlation matrix and some descriptive statistics of the dependent, explanatory and control variables employed in the equations of steps (1) and (2), in order to check for possible multicollinearity issues. However, none of the relationships appears to be large enough to warrant concern for multicollinearity. We also computed the Variance Inflation Factors (VIFs) for both equations of each step. None of the values is above the threshold of 10.00 , thus ruling out potential multicollinearity problems.

- Insert table 6 about here -

\section{RESULTS}

\subsection{Findings}

Given the nature of the dependent variables, we employ Probit models using a robust variance estimator in both Step (1) and Step (2). Table 7 shows the results concerning hypothesis 1. Namely. columns 1.a and 1.b are associated to Step (1), as they report the coefficients of the estimation of equations (1.a) and (1.b), respectively, while columns 2.a and 2.b are associated to step (2), as they show the results of the estimation of equations (2.a) and (2.b), respectively.

\footnotetext{
${ }^{11}$ The two-step methodology adopted in this paper requires at least one excluded explanatory variable that influences step (1) and not step (2). Our exclusion restrictions are the variables Repeated Captive Experience and Repeated Outsourcing Experience in equation 1.a, and Repeated Growing Captive Experience, Repeated Growing Outsourcing Experience, Repeated Non-Growing Captive Experience and Repeated Non Growing Outsourcing Experience in equation 1.b.
} 
Estimates for Step (1) confirm the temporal interdependence of entry choices (Chan \& Makino, 2007; Chang \& Rosenzweig, 2001; Guillen, 2003; Lu, 2002; Padmanabhan \& Cho, 1999; Swoboda et al., 2015). Indeed, the variables reflecting the captive past entry modes show negative and significant coefficients, i.e. Repeated Captive Experience with a coefficient of $-0.167(\mathrm{p}<0.01)$ (column 1.a), and Repeated Growing Captive Experience with a coefficient of -0.305 ( $<<0.001)$ (column 1.b). Conversely, the variables reflecting the outsourcing past entry modes, i.e. Repeated Outsourcing Experience (column 1.a) and Repeated Growing Outsourcing Experience (column 1.b), display positive (respectively 0.213 and 0.362 ) and significant ( $<<0.001$ in both cases) correlations with the dependent variable. Therefore, results confirm that firms tend to replicate the previous entry modes of the same type. In particular, the mindful entry-choice model shows that firms tend to repeat the past successful experiences.

In step (2), we find that the variable Inertial Entry Fit is not statistically significant $(\mathrm{p}=0.276)$ (column 3). Conversely, the variable Mindful Entry Fit is statistically significant with a positive sign $(\mathrm{p}=0.022)$ and a coefficient of 0.642 (column 4), thus signalling that offshoring firms relying on mindful repetition of their entry modes foster the growth perspectives of their initiatives more than offshoring firms relying on inertial repetition of their entry modes ${ }^{12}$. Firms analysing their previous experiences and their success drivers, indeed, are able to foster learning and develop knowledge and, ultimately, enhance the growth perspective of their offshoring initiatives over time. Hence, our hypothesis 1 is fully verified.

Regarding the control variables in step (1), we find that country-specific experience increases the probability of undertaking captive entry modes $(\mathrm{p}<0.001)$, as suggested by the traditional stage theories (e.g., Johanson \& Vahlne, 1977). As firms gain familiarity with the host country, they face a lower liability of foreignness, thus increasing the level of commitment through captive entry modes. It also turns out that larger firms $(\mathrm{p}<0.05)$ and firms operating in IT industries $(\mathrm{p}<0.001)$ are more likely

\footnotetext{
${ }^{12}$ We performed a post-estimation Chi-Square test in order to verify whether the coefficient of the variable Inertial Entry Fit is significantly different from the coefficient of the variable Mindful Entry Fit. The test rejects the null hypothesis that the difference between the two coefficients is equal to zero (Chi-square $=8.923$, $p$-value $=0.0028$ ), thus confirming that the mindful entry fit has a significantly larger effect on growth perspective than the inertial entry fit.
} 
to undertake captive investments, probably due to the high amount of resources required by the latter and to the need of IT firms to keep a tight control of foreign operations for security and quality reasons. Additionally, results show that outsourcing initiatives are less likely in countries with high cultural distance ( $p<0.01$ in column 1.a and $\mathrm{p}<0.05$ in column 1.b) and high governance infrastructure $(\mathrm{p}<0.001)$, since familiar and stable environments enable firms to invest with a higher commitment. Conversely, outsourcing seems to be more likely if the home country is the U.S. ( $p<0.05$ in column 1.b). Finally, captive investments are more likely in case of colocation of manufacturing firms ( $\mathrm{p}<0.01$ in column 1.a and $\mathrm{p}<0.05$ in column 1.b) - probably because synergies across activities are better managed through vertical integration - and when the main driver is market penetration $(\mathrm{p}<0.10)$ - probably because captive investments enable a higher rent appropriation.

As regards the control variables in step (2), the outsourcing mode of entry $(\mathrm{p}<0.001)$, the cultural distance $(\mathrm{p}<0.10)$, the governance infrastructure $(\mathrm{p}<0.001)$ and the age of the initiative $(p<0.001)$ reduce the likelihood of an expansion of the offshoring venture. Therefore, results suggest that an increase in growth perspective is more likely in the case of captive mode of entry.

Additionally, results show that greater cultural distance reduces the likelihood of an expansion of the foreign venture, and that long-established offshoring ventures are subject to exploitative behaviours. As regards the governance infrastructure, it is likely that this variable captures stable business environments that are not subject to companies' expansion plans, which explains the negative sign $(\mathrm{p}<0.001)$. Finally, firms driven by the access to qualified talents $(\mathrm{p}<0.001)$ and by labour cost reduction $(\mathrm{p}<0.05)$ are more likely to expand their businesses. In the first case, the positive correlation is probably related with the aspiration to achieve new resources typical of expanding firms, while, in the second case, it is connected with the need to obtain greater economies of scale.

- Insert table 7 about here -

Table 8 shows the results concerning hypothesis 2 . Columns 1 and 2 introduce the interaction term in equations 2.a and 2.b, columns 3 and 4 split equation 2.a between outsourcing and captive subsamples, respectively, and columns 5 and 6 split equation 2.b between outsourcing and captive subsample, respectively. 
Both interaction terms show a negative coefficient (columns 1 and 2), although only the interaction between outsourcing and inertial entry fit turns out to be significant $(\mathrm{p}<0.05)$. Given the non-linearity nature of our model, we plotted the results in order to gain more insights on the moderation effect. Figure 2.a shows the interaction between outsourcing and inertial entry fit, while figure $2 . b$ the interaction between outsourcing and mindful entry fit. The former clearly shows that the effect of inertial entry fit is positive only in case of captive entry mode, while becoming negative in case of outsourcing; conversely, the latter shows that mindful entry fit is simply more positive in case of captive than in case of outsourcing entry mode. The analyses on subsamples confirm that the inertial $(\mathrm{p}<0.05)$ and mindful $(\mathrm{p}<0.01)$ entry fits have a positive and significant effect on growth perspective only in case of captive (columns 4 and 6) initiatives, while the same effect is not significant in case of outsourcing initiatives (columns 3 and 5). Hence, hypothesis 2 turns out to be verified, although with a stronger effect for the inertial than for the mindful repetition.

- Insert table 8 about here -

4.2 Robustness check and additional analysis

We conducted additional robustness checks in order to verify the reliability of our results. More specifically, we replicated the second step using as independent variables the Inertial Repeated Entry Mode and the Mindful Repeated Entry Mode instead of the Inertial Entry Fit and the Mindful Entry Fit. The aim is to provide a direct connection between previous entry mode experience, on the one hand, and growth perspective, on the other hand, without relying on the fit from the first step. This latter variable, indeed, captures the extent to which a firm complies with an entry mode choice that is driven not only by previous entry mode experiences, but also by other covariates. Conversely, by employing directly the variables Inertial Repeated Entry Mode and Mindful Repeated Entry Mode, we are able to assess the direct effect of different types of previous entry mode experience on the growth perspectives.

The Inertial Repeated Entry Mode accounts for the number of previous initiatives that adopted the same mode of entry regardless of previous outcome, while the Mindful Repeated Entry 
Mode is the number of previous initiatives that adopted the same mode of entry, taking into consideration the outcome of the former initiatives (where failures are accounted with a negative sign, while successes with a positive one and then the two measures are summed) ${ }^{13}$. Following our conceptual framework, the former variable is expected to have a weaker correlation with the dependent variable than the latter on the growth perspective.

Equations (3.a) and (3.b) are estimated in our robustness check and the related results (which are available upon request) substantially confirm our previous findings.

$$
\begin{aligned}
& \text { Outcome }_{i}=\alpha+\beta \cdot \text { Inertial repeated entry mode } i+\gamma \cdot \text { controls }_{i}+\varepsilon_{i} \\
& \text { Outcome }_{i}=\alpha+\beta \cdot \text { Mindful repeated entry mode } e_{i}+\gamma \cdot \text { controls }_{i}+\varepsilon_{i}
\end{aligned}
$$

Given that the extent to which a firm is willing and able to trigger the learning mechanisms is likely to depend also on the specific roles assigned to the subsidiary or supplier of the new venture, we explored whether the drivers of offshoring have a moderating effect on the inertial and mindful repetition. Specifically, we tested the interaction effect between the entry fits, on the one hand, and the access to talented employees, the cheap labour costs, the co-location with manufacturing activities and the market-seeking drivers, on the other hand. Results, which are available upon request, show that when the offshoring initiatives are driven by the access to talented employees, the impact of both the inertial and mindful entry fit on growth perspective is magnified. A possible explanation is that the access to talents is likely to maximize the transfer of information and knowledge, which is typically embedded in individuals, thus amplifying the effect of the learning mechanisms underlying the inertial and mindful learning on the growth perspective of the new venture. We also found that, when the offshoring initiative is driven by the co-location with manufacturing activities, the effect of mindful learning on growth perspective is strengthened. This is likely to be due to the combination of

${ }^{13}$ See Diwas, Staats \& Gino (2013) 
the positive effects arising from the mindful learning approach and from the strong synergies underlying the co-location of manufacturing and business activities.

\section{DISCUSSION AND CONCLUDING REMARKS}

This paper studies the relationship between different types of repetition of entry choices and growth perspectives of offshoring ventures. Although several works have already identified the temporal interdependence of entry choices, results on whether entry-specific experience fosters learning and, ultimately, growth perspectives are still ambiguous.

The inter-dependence of entry choices has been traditionally attributed to the need of reducing ambiguity as long as greater familiarity with organizational-specific attributes decreases the perceived uncertainty. In our paper we try to identify two main learning mechanisms underlying the repetition of entry choice, i.e. the experiential learning and the creation of new organizational learning both allowing the reduction of liability of foreignness,. However, when learning is inertial, firms tend to be over-confident with the organizational routines adopted in the past and to be subject to lock-in effects and organizational inertia (Petersen et al., 2008). Indeed, we find that the inertial repetition of previous entry modes is not positively associated to the future growth perspectives of offshoring ventures. Conversely, the mindful repetition of previous entry modes is an incremental and selfgenerating process as firms recombine, develop and apply their expanding organizational routines thus fostering the growth perspectives of their foreign initiatives.

We also find that repetition of captive entry mode displays a more positive effect on the growth perspective than the repetition of outsourcing entry mode, probably due to the more direct and straightforward possibility to transfer information and knowledge associated to the former, which is likely to increase the effectiveness of the learning mechanisms. Our results show that the captive entry mode is able to trigger a positive effect on growth perspective even in case of inertial repetition, while on the opposite side the same type of repetition turns out to be detrimental in case of outsourcing entry mode. Overall, our empirical analysis confirms our theoretical framework, thus providing 
further understanding to the relationship between experience, learning and entry mode for foreign initiatives (in the case of business services offshoring).

We believe that our paper contributes to the ongoing debate on entry mode, which is still lively in the IB literature. Indeed, our work departs from the attempt to answer some of the questions raised by the recent revival of the debate on (the need of more) entry mode studies. The selection of the entry mode is one of the key concerns for managers of companies investing abroad; despite the large number of papers on this topic, "we still lack clear tools to help managers to make their choices" (Brouthers, 2013: 14). In addition, following the question posed by Shaver (2013) on whether we need further entry mode studies, Hennart and Slangen (2015) argue that entry mode studies require an evolutionary approach accounting for the role of previous experience. One of the most promising research in this field regards how to choose the entry mode that enables and fosters firms' competitiveness (Hennart \& Slangen, 2015; Martin, 2013). In particular, it is not clear whether firms "merely consider the frequency with which specific modes were chosen previously", or "take into account the ex post performance of prior choices and hence learn from them", and, if they learn from prior experience, "from which types of experiences do they learn more" (Hennart \& Slangen, 2015: 118). Thus, we add to previous literature on entry modes by inquiring how different types of entryspecific experience lead to different types of learning and, hence, different growth perspectives for the offshoring present initiative. In doing so, we contribute to the managerial and international business literature by showing that, when considering repeated entry modes, Transaction Cost Economics by itself is insufficient to explain MNEs' critical managerial issues such as the need to create and develop capabilities and processes (Teece, 2014). The Dynamic Capability approach can provide a complementary view by highlighting the role of the learning underlying the repetition of the entry mode. Indeed, previous entry-specific experience might allow decreasing liability of foreignness and overcoming contractual and managerial uncertainties, but it is also likely to lead to organizational inertia, while the development of the most important learning capabilities stems from the iteration of expanding organizational routines leading to a selective and self-reinforcing wisdom (i.e. mindful learning). We also offer novel insights on the different learning process underlying captive and outsourcing. 
We finally provide a contribution to one (probably the most important) of the five decision making questions concerning offshoring (Hätönen \& Eriksson, 2009; Pereira \& Malik, 2015), i.e. when to outsource or keep in-house. We show, indeed, the need to take into account the previous entry-specific experience when analysing this strategic decision and we highlight the positive consequences arising from the adoption of an entry choice model that takes into consideration the increasing and decreasing levels of the competitive advantage underlying previous growing and nongrowing experiences.

In terms of managerial implications, our results warn practitioners against the risk of adopting inertial repetition of previous entry modes, especially in case of outsourcing. The results of this research suggest that decision makers should carefully inquire the drivers of the success and failures of previous international activities, and particular attention should be granted to the repository of organizational routines (e.g. the workers) and to the mechanisms (e.g. job rotation) that enable the transmission of organizational knowledge across space and time within the firm.

We believe that the present work opens possible future research avenues. First, future works should consider other types of experience (e.g. function-specific, industry-specific, supplier-specific etc.) that might be a source of knowledge and learning enabling the growth of the initiative. Second, future research should consider that not all experiences are equal; older ventures, for instance, might prevent smooth knowledge sharing as long as the context might have deeply changed over time; likewise, the geographic distribution of previous repeated entry modes might also play a role in assessing the type of learning the company can rely on to foster growth. Third, alternative subjective and/or objective dependent variables could be adopted in step (2) in order to investigate other facets of the outcome of foreign ventures. Fourth, future works should disentangle the relationship between the repetition of entry modes and outcome considering also intermediate entry modes such as joint ventures and alliances, and to better disentangle the specific learning arising from each type of entry mode. Fifth, future econometric analysis should be based on panel data in order to study a timevarying phenomenon. Finally, future researches should also clarify the role of unsuccessful initiatives in order to understand if they (i) lead to quit any future offshoring project; (ii) induce to change the 
entry mode of the actual or future ventures, or instead; (iii) trigger a learning-from-mistakes process without changing the entry mode structure. 


\section{REFERENCES}

Anderson, E. \& Gatignon, H. (1986). Modes of foreign entry: a transaction cost analysis and propositions. Journal of International Business Studies, 17: 1-26.

Argote, L. (2006). Introduction to mindfulness. Organization Science, 17(4): 501.

Argote, L. \& Epple, D. (1990). Learning curves in manufacturing. Science, 247(4945): 920-924.

Argote, L. \& Miron-Spektor, E. (2011). Organizational learning: from experience to knowledge. Organization Science, 22(5): 1123-1137.

Aulakh, P. S., Kotabe, M. \& Sahay, A. (1996).Trust and performance in cross-border marketing partnerships: a behavioural approach. Journal of International Business Studies, 27(4): 1005-1032.

Benito, G. R. G. \& Gripsrud, G. (1992). The expansion of foreign direct investments: discrete rational location choices or a cultural learning process? Journal of International Business Studies, 23(3): 461-476.

Brouthers, K. D. (2002). Institutional, cultural and transaction cost influences on entry mode choice and performance. Journal of International Business Studies, 33(2): 203-221.

Brouthers, K. D. (2013). Retrospective on entry mode and performance. Journal of International Business Studies, 44: 14-22.

Cantwell, J. (2014). Revisiting international business theory: a capabilities-based theory of the MNE. Journal of International Business Studies, 45: 1-7.

Castañer, X., Mulotte, L., Garrette, B., \& Dussauge, P. (2013). Governance mode vs. governance fit: performance implications of make-or-ally choices for product innovation in the world wide aircraft industry 1942-2000. Strategic Management Journal, 35(9): 1386-1397.

Chan, C. M., \& Makino, S. (2007). Legitimacy and multi-level institutional environments: implications for foreign subsidiary ownership structure. Journal of International Business Studies, 38(4): 621-638.

Chang, S. J. (1995). International expansion strategy of Japanese firms: capability building through sequential entry. The Academy of Management Journal, 38(2): 383-407. 
Chang, S. J., \& Rosenzweig, P. M. (2001). The choice of entry mode in foreign direct investment. Strategic Management Journal, 22: 747-776.

Cohen, W. M., \& Levinthal, D. A. (1990). Absorptive capacity: a new perspective on learning and innovation. Administrative Science Quarterly, 35(1): 128-152.

Contractor, F., Kumar, V., Kundu, S. \& Pedersen T. (2010). Reconceptualising the firm in a world of outsourcing and offshoring: The organizational and geographical relocation of high-value company functions. Journal of Management Studies, 47(8): 1417-1433.

Delios, A. \& Beamish, P.W. (2001). Survival and profitability: the roles of experience and intangible assets in foreign subsidiary performance. The Academy of Management Journal, 44(5): 1028-1038.

Di Gregorio, D., Musteen, M., \& Thomas, D. E. (2009). Offshore outsourcing as a source of international competitiveness for SMEs. Journal of International Business Studies, 40(6): 969-988.

Dikova, D., \& Van Witteloostuijn, A. (2007). Foreign direct investment mode choice: entry and establishment modes in transition economies. Journal of International Business Studies, 38(6): 1013-1033.

Diwas, K.C., Staats, B.R., \& Gino, F. (2013). Learning from my success and from others' failure: evidence from minimally invasive cardiac surgery. Management Science, 59 (11): 2435-2449.

Dutton, J.M. \& Thomas, A. (1984). Treating progress functions as a managerial opportunity. Academy of Management Review, 9(2): 235-247.

Elia, S., Caniato, F., Luzzini, D., \& Piscitello, L. (2014). Governance and performance in global sourcing of services: does a mistake always hurt performance? Global Strategy Journal, 4(3): 181199.

Erramilli, M. K. (1991). The experience factor in foreign market entry behaviour of service firms. Journal of International Business Studies, 22(3): 479-501.

Foss, N. J., \& Pedersen, T. (2002). Transferring knowledge in MNCs: The role of sources of subsidiary knowledge and organizational context. Journal of International Management, 8(1): 4967.

Gao, G.Y. \& Pan, Y. (2010). The pace of MNEs' sequential entries: cumulative entry experience and the dynamic process. Journal of International Business Studies, 41(9): 1572-1580. 
Gao, G.Y., Pan, Y., Lu, J. \& Tao, Z. (2008). Performance of multinational firms' subsidiaries: influence of cumulative experience. Management International Review, 48(6): 749-768.

Gersick, C. J. G. \& Hackman, J. R., (1990). Habitual routines in task performance teams. Organizational Behavior and Human Decision Processes, 47(1): 65-97.

Globerman, S. \& Shapiro, D. (2003). Governance infrastructure and US foreign direct investment. Journal of International Business Studies, 34(1): 19-39.

Gooris J. \& Peeters C. (2016). Fragmenting global business processes: A protection for proprietary information. Journal of International Business Studies, 47(5), 535-562.

Greene, W. (2010). Testing hypotheses about interaction terms in nonlinear models. Economics Letters, 107 (2), 291-296.

Guillen, M. (2003). Experience, imitation, and the sequence of foreign entry: wholly owned and jointventure manufacturing by South Korean firms and business groups in China, 1987-1995. Journal of International Business Studies, 34(2): 185-198.

Hätönen, J., \& Eriksson, T. (2009). 30+ years of research and practice of outsourcing - Exploring the past and anticipating the future. Journal of International Management, 15 (2): 142-155.

Heckman, J., (1979). Sample selection bias as a specification error. Econometrica, 47(1): 153-161.

Henisz, W. J., \& Macher, J. T. (2004). Firm-and country-level trade-offs and contingencies in the evaluation of foreign investment: The semiconductor industry, 1994-2002. Organization Science, 15(5): 537-554.

Hennart, J-F. \& Slangen A., (2015). Yes, we really do need more entry mode studies! A commentary on Shaver. Journal of International Business Studies, 46(1): 114-122.

Hill, C. W. L. (2011). International Business. Competing in the global marketplace. McGrawHill/Irwin, New York.

Hofstede, G. (2001), Culture's consequences: comparing values, behaviours, institutions and organizations across nations, Thousand Oaks CA Sage Publications, second edition.

Hult, G. T. M., Ketchen Jr., D. J., Griffith, D. A., Chabowski, B. R., Hamman, M. K., Dykes, B. J., Pollitte, W. A., \& Cavusgil, S. T. (2008). An assessment of the measurement of performance in international business research. Journal of International Business Studies, 39(6): 1064-1080. 
Hutzschenreuter, T., Pedersen, T., \& Volberda, H. W. (2007). The role of path dependency and managerial intentionality: a perspective on international business research. Journal of International Business Studies, 38(7): 1055-1068.

Johanson, J., \& Vahlne, J-E. (1977). The internationalization process of the firm: model of knowledge development and increasing foreign market commitments. Journal of International Business Studies, 8(1): 23-32.

Johanson, J., \& Vahlne, J-E. (2009). The Uppsala internationalization process model revisited: From liability of foreignness to liability of outsidership. Journal of international business studies, 40(9): $1411-1431$.

Kaplan R.S., \& Norton D.P. (2001). Transforming the balanced scorecard from performance measurement to Strategic Management: Part I. Accounting Horizons, 15(1): 87-104.

Kogut, B. \& Singh, H. (1988). The effect of national culture on the choice of entry mode. Journal of International Business Studies, 19(3): 411-432.

Larsen, M.M, \& Lyngsie, J. (2017). Ambiguous adaptation: The effect of contract duration and investments in relational mechanisms on premature relationship termination. Long Range Planning, forthcoming (available at:

http://www.sciencedirect.com/science/article/pii/S0024630116302588)

Leiblein M. J., Reuer J. J., \& Dalsace F. (2002). Do make or buy decisions matter? The influence of organizational governance on technological performance. Strategic Management Journal, 23(9): 817-833.

Levinthal, D. \& Rerup, C. (2006). Crossing an apparent chasm: bridging mindful and less mindful perspectives on organizational learning. Organization Science, 17(4): 502-513.

Levitt., B., \& March, J. G. (1988). Organizational learning. Annual Review of Sociology, 14 (1): 319340.

Lewin, A. Y., \& Massini, S. (2003). Knowledge creation and organizational capabilities of innovating and imitating firms. In H. Tsoukas \& Mylonopoulos, N. (Ed.) Organizations as knowledge systems: knowledge, learning and dynamic capabilities. Palgrave-Macmillan, New York: 209-237. 
Lewin, A. Y., Massini, S., \& Peeters, C. (2009). Why are companies offshoring innovation? The emerging global race for talent. Journal of International Business Studies, 40(6): 901-925.

Lewin, A. Y., Massini, S., \& Peeters, C. (2011). Microfoundations of internal and external absorptive capacity routines. Organization Science, 22(1): 81-98.

Lewin, A. Y., \& Peeters, C. (2006). Offshoring work: business hype or the onset of fundamental transformation? Long Range Planning, 39(3), 221-239.

Lu, J. (2002). Intra and inter-organizational imitative behaviour: institutional influences on Japanese firms' entry mode choice. Journal of International Business Studies, 33(1): 19-37.

Luo, Y. \& Peng M.W. (1999). Learning to compete in a transition economy: experience, environment and performance. Journal of International Business Studies, 30(2): 269-295.

Manning, S., Massini, S., \& Lewin, A. Y. (2008). A dynamic perspective on next-generation offshoring: the global sourcing of science and engineering talent. The Academy of Management Perspectives, 22(3): 35-54.

March, J.G. (1991). Exploration and exploitation in organizational learning. Organization Science, 2: 71-87.

March, J.G., \& Olsen, J. P. (1989). Rediscovering institutions: the organizational basis of politics. Free Press, New York.

Martin, X. (2013). Solving theoretical and empirical conundrums in international strategy research: linking foreign entry mode choices and performance. Journal of International Business Studies, 44: $28-41$.

Mudambi, R. (1998). The role of duration in multinational investment strategies. Journal of International Business Studies, 29(2): 239-262.

Murtha, T. P. (2004). The metanational firm in context: Competition in knowledge-driven industries. Advances in International Management, 16: 101-136.

Nelson, R. R. \& Winter, S. G. (1982). An evolutionary theory of economic change. Belknap PressHarvard University Press, Cambridge.

Nonaka, I. (1994). A dynamic theory of organizational knowledge creation. Organization Science, 5(1): 14-37. 
Nonaka, I., \& Takeuchi, H. (1995). The knowledge creating economy: How Japanese companies create the dynamics of innovation. New York: Oxford University Press.

Oshri, I, Kotlarsky, J. \& Willcocks, L.P. (2015). The Handbook of Global Outsourcing and Offshoring, Palgrave MacMillan, London.

Padmanabhan, P. \& Cho, K. (1999). Decision-specific experience in foreign ownership and establishment strategies: evidence from Japanese firms. Journal of International Business Studies, 30(1): $25-44$.

Pan, Y., \& Tse, D. K. (2000). The hierarchical model of market entry modes. Journal of International Business Studies, 31(4): 535-554.

Peng, M. W., Sun, S. L., Pinkham, B., \& Chen, H. (2009). The Institution-Based View as a Third Leg for a Strategy Tripod. The Academy of Management Perspectives, 23(3): 63-81.

Pereira, V., \& Malik., A., (2015). Human Capital Management in the Indian IT/BPO Industry. London: Palgrave Macmillan, London.

Perkins, S. E. (2014). When does prior experience pay? Institutional experience and the multinational corporation. Administrative Science Quarterly, 59(1): 145-181.

Petersen, B., Pedersen, T., \& Lyles, M. A. 2008. Closing knowledge gaps in foreign markets. Journal of International Business Studies, 39: 1097-1113.

Shaver M., (1998). Accounting for endogeneity when assessing strategy performance: does entry mode choice affect FDI survival? Management Science, 44(4): 571- 585.

Shaver, J. M. (2013). Do we really need more entry mode studies? Journal of International Business Studies, 44: 23-27.

Swoboda, B., Elsner, S. \& Olejnik, E. (2015). How do past mode choices influence subsequent entry? A study on the boundary conditions of preferred entry modes of retail firms. International Business Review, 24(3): 506-517.

Tallman, S. B. (2003). Dynamic Capabilities. Oxford University Press.

Teece, D. J. (2014). A dynamic capabilities-based entrepreneurial theory of the multinational enterprise. Journal of International Business Studies, 45(8): 8-37. 
Teece, D., Pisano, G., \& Shuen, A. (1997). Dynamic capabilities and strategic management. Strategic Management Journal, 18(7): 509-533.

Tihanyi, L., Griffith, D. A. \& Russel, C. J. (2005). The effect of cultural distance on entry mode choice, international diversification, and MNE performance: a meta-analysis. Journal of International Business Studies, 36(3): 270-283.

Vermeulen, F. \& Barkema, H. (2001). Learning through acquisitions. Academy of Management Journal, 44(3): 457-476.

Weick, K.E. \& Sutcliffe, K.M. (2006). Mindfulness and the quality of organizational attention. Organization Science, 17(4): 514-524.

Williamson, O. E. (1975). Markets and hierarchies: analysis and antitrust implications. Free Press, New York.

Woodcock, C. P., Beamish, P. W. \& Makino, S. (1994). Ownership-base entry mode strategies and international performance. Journal of International Business Studies. 25(2): 253-273.

Youngdahl, W., Ramaswamy K., \& Dash K. (2010). Service Offshoring: the evolution of offshore operations. Journal of Operations and Production Management, 30(8): 798-820. 
TABLES

Table 1 - Home country distribution of offshoring initiatives

\begin{tabular}{lc}
\hline Home country & $\begin{array}{c}\text { No } \\
(\%)\end{array}$ \\
\hline Australia & 2 \\
Belgium & $(0.49)$ \\
Denmark & $(8.29)$ \\
France & 6 \\
The Netherlands & $(1.46)$ \\
Spain & 3 \\
Switzerland & $(0.73)$ \\
United Kingdom & 66 \\
& $(16.10)$ \\
United States & 8 \\
Total & $(1.95)$ \\
& 8 \\
Source: Our & $(1.95)$ \\
& 10 \\
\end{tabular}

Source: our elaboration on ORN data 
Table 2 - Host country distribution of offshoring initiatives

\begin{tabular}{|c|c|}
\hline Host country & $\begin{array}{l}\text { No } \\
(\%)\end{array}$ \\
\hline Argentina & $\begin{array}{c}4 \\
(0.98)\end{array}$ \\
\hline Australia & $\begin{array}{c}2 \\
(0.49)\end{array}$ \\
\hline Austria & $\begin{array}{c}1 \\
(0.24)\end{array}$ \\
\hline Brazil & $\begin{array}{c}5 \\
(1.22)\end{array}$ \\
\hline Canada & $\begin{array}{c}11 \\
(2.68)\end{array}$ \\
\hline China & $\begin{array}{c}46 \\
(11.22)\end{array}$ \\
\hline Colombia & $\begin{array}{c}3 \\
(0.73)\end{array}$ \\
\hline Costa Rica & $\begin{array}{c}4 \\
(0.98)\end{array}$ \\
\hline Czech Republic & $\begin{array}{c}4 \\
(0.98)\end{array}$ \\
\hline Denmark & $\begin{array}{c}1 \\
(0.24)\end{array}$ \\
\hline Ecuador & $\begin{array}{c}1 \\
(0.24)\end{array}$ \\
\hline El Salvador & $\begin{array}{c}2 \\
(0.49)\end{array}$ \\
\hline Finland & $\begin{array}{c}3 \\
(0.73)\end{array}$ \\
\hline France & $\begin{array}{c}7 \\
(1.71)\end{array}$ \\
\hline Germany & $\begin{array}{c}11 \\
(2.68)\end{array}$ \\
\hline Greece & $\begin{array}{c}1 \\
(0.24)\end{array}$ \\
\hline Hungary & $\begin{array}{c}8 \\
(1.95)\end{array}$ \\
\hline India & $\begin{array}{c}141 \\
(34.39)\end{array}$ \\
\hline Indonesia & $\begin{array}{c}3 \\
(0.73)\end{array}$ \\
\hline Ireland & $\begin{array}{c}4 \\
(0.98)\end{array}$ \\
\hline Italy & $\begin{array}{c}4 \\
(0.98)\end{array}$ \\
\hline Jamaica & $\begin{array}{c}4 \\
(0.98)\end{array}$ \\
\hline Japan & $\begin{array}{c}3 \\
(0.73)\end{array}$ \\
\hline Luxembourg & $\begin{array}{c}1 \\
(0.24)\end{array}$ \\
\hline Malaysia & $\begin{array}{c}6 \\
(1.46)\end{array}$ \\
\hline Mexico & $\begin{array}{c}16 \\
(3.90)\end{array}$ \\
\hline The Netherlands & $\begin{array}{c}4 \\
(0.98)\end{array}$ \\
\hline New Zealand & $\begin{array}{c}1 \\
(0.24)\end{array}$ \\
\hline Norway & $\begin{array}{c}4 \\
(0.98)\end{array}$ \\
\hline Pakistan & $\begin{array}{c}2 \\
(0.49)\end{array}$ \\
\hline Peru & $\begin{array}{c}1 \\
(0.24)\end{array}$ \\
\hline Philippines & $\begin{array}{c}32 \\
(7.80)\end{array}$ \\
\hline Poland & $\begin{array}{c}10 \\
(2.44)\end{array}$ \\
\hline Portugal & $\begin{array}{c}2 \\
(0.49)\end{array}$ \\
\hline Romania & $\begin{array}{c}1 \\
(0.24)\end{array}$ \\
\hline Russia & $\begin{array}{c}7 \\
(1.71)\end{array}$ \\
\hline Singapore & $\begin{array}{c}6 \\
(1.46)\end{array}$ \\
\hline Slovakia & $\begin{array}{c}4 \\
(0.98)\end{array}$ \\
\hline
\end{tabular}


South Africa

South Korea

Spain

Sweden

Taiwan

Thailand

Turkey

United Kingdom

United States

Uruguay

Total
6

$(1.46)$

3
$(0.73)$

(0.73)

5

(1.22)

2
$(0.49)$

1

(0.24)

1

$(0.24)$

9
$(2.20)$

$(2.20)$
9

(2.20)

1

(0.24)

410 (100.00)

Source: our elaboration on ORN data 
Table 3 - Business function and sector distribution

\begin{tabular}{|c|c|}
\hline Business function & $\begin{array}{l}\text { No } \\
(\%)\end{array}$ \\
\hline Analytical/Knowledge Services & $\begin{array}{c}18 \\
(4.39)\end{array}$ \\
\hline Call Centre/Customer contact & $\begin{array}{c}74 \\
(18.05)\end{array}$ \\
\hline Engineering Services & $\begin{array}{c}41 \\
(10.00)\end{array}$ \\
\hline Finance/Accounting & $\begin{array}{c}54 \\
(13.17)\end{array}$ \\
\hline Human Resources & $\begin{array}{c}15 \\
(3.66)\end{array}$ \\
\hline Information Technology & $\begin{array}{c}73 \\
(17.80)\end{array}$ \\
\hline Legal Services & $\begin{array}{c}5 \\
(1.22)\end{array}$ \\
\hline Marketing and Sales & $\begin{array}{c}45 \\
(10.98)\end{array}$ \\
\hline Product Design & $\begin{array}{c}12 \\
(2.93)\end{array}$ \\
\hline Research \& Development & $\begin{array}{c}13 \\
(3.17)\end{array}$ \\
\hline Software Development & $\begin{array}{c}29 \\
(7.07)\end{array}$ \\
\hline Supply Chain and Facilities & $\begin{array}{c}31 \\
(7.56) \\
\end{array}$ \\
\hline Total & $\begin{array}{c}410 \\
(100.00)\end{array}$ \\
\hline Industry & $\begin{array}{c}\text { No } \\
(\%)\end{array}$ \\
\hline Aerospace and defence & $\begin{array}{c}7 \\
(1.71)\end{array}$ \\
\hline Arts, entertainment and recreation & $\begin{array}{c}4 \\
(0.98)\end{array}$ \\
\hline Automotive & $\begin{array}{c}1 \\
(0.24)\end{array}$ \\
\hline Energy, utilities and mining & $\begin{array}{c}4 \\
(0.98)\end{array}$ \\
\hline Financial services & $\begin{array}{c}85 \\
(20.73)\end{array}$ \\
\hline Healthcare & $\begin{array}{c}1 \\
(0.24)\end{array}$ \\
\hline Manufacturing & $\begin{array}{c}79 \\
(19.27)\end{array}$ \\
\hline Pharmaceuticals and life sciences & $\begin{array}{c}9 \\
(2.20)\end{array}$ \\
\hline Professional services & $\begin{array}{c}24 \\
(5.85)\end{array}$ \\
\hline Retail and consumer goods & $\begin{array}{c}21 \\
(5.12)\end{array}$ \\
\hline Software and IT services & $\begin{array}{c}106 \\
(25.85)\end{array}$ \\
\hline Telco & $\begin{array}{c}24 \\
(5.85)\end{array}$ \\
\hline Transportation and logistics & $\begin{array}{c}16 \\
(3.90)\end{array}$ \\
\hline Other & $\begin{array}{c}29 \\
(7.07)\end{array}$ \\
\hline Total & $\begin{array}{c}410 \\
(100.00) \\
\end{array}$ \\
\hline
\end{tabular}

Source: our elaboration on ORN data 
Table 4 - Example of the procedure employed to build the explicative variables of the equations of step 1: all the observations of the example refers to a single firm.

\begin{tabular}{ccc|cc|cccc}
\hline \multicolumn{3}{c}{ Original data } & \multicolumn{2}{c}{ Equation 1.a } & \multicolumn{2}{c}{ Equation 1.b } \\
\hline $\begin{array}{c}\text { Year of } \\
\text { the } \\
\text { initiative }\end{array}$ & Entry mode & $\begin{array}{c}\text { Growing } \\
\text { Experience }\end{array}$ & $\begin{array}{c}\text { Repeated } \\
\text { captive } \\
\text { experience }\end{array}$ & $\begin{array}{c}\text { Repeated } \\
\text { outsourcing } \\
\text { experience }\end{array}$ & $\begin{array}{c}\text { Repeated } \\
\text { growing } \\
\text { captive } \\
\text { experience }\end{array}$ & $\begin{array}{c}\text { Repeated } \\
\text { non- } \\
\text { nepeated } \\
\text { growing } \\
\text { outsourcing } \\
\text { experience } \\
\text { growing } \\
\text { captive } \\
\text { experience } \\
\text { outsourcing } \\
\text { experience }\end{array}$ \\
\hline 1999 & Outsourcing & 0 & 0 & 0 & 0 & 0 & 0 \\
2000 & Captive & 0 & 0 & 1 & 0 & 0 & 0 \\
2001 & Captive & 1 & 1 & 1 & 0 & 0 & 1 \\
2002 & Captive & 0 & 2 & 1 & 1 & 0 & 1 \\
2005 & Outsourcing & 1 & 3 & 1 & 1 & 0 & 1 \\
\hline
\end{tabular}


Table 5 - Exploratory Factor Analysis on location variables (Principal Components with Varimax

\section{Rotation)}

\begin{tabular}{|c|c|c|c|c|c|c|}
\hline $\begin{array}{c}\text { First order } \\
\text { construct }\end{array}$ & Items & Source & Description & Scale & Loading & Alpha \\
\hline \multirow{5}{*}{$\begin{array}{c}\text { Market } \\
\text { Attractiveness }\end{array}$} & Gross Domestic Product & WCY & Gross Domestic Product & $\begin{array}{c}\text { US\$ } \\
\text { billions }\end{array}$ & 0.99 & \multirow{5}{*}{0.79} \\
\hline & $\begin{array}{l}\text { Gross Fixed Capital } \\
\text { Formation }\end{array}$ & WCY & $\begin{array}{l}\text { Total value of acquisitions of domestic firms } \\
\text { (net of disposals) of fixed capital during a } \\
\text { specific period plus the value increments of } \\
\text { non-productive assets generated by } \\
\text { productive activities }\end{array}$ & $\begin{array}{c}\text { US\$ } \\
\text { billions }\end{array}$ & 0.95 & \\
\hline & $\begin{array}{l}\text { Direct Investment } \\
\text { Inflows Inward }\end{array}$ & WCY & Direct Investment Inflows Inward & $\begin{array}{c}\text { US\$ } \\
\text { billions }\end{array}$ & 0.87 & \\
\hline & $\begin{array}{l}\text { Government } \\
\text { Consumption } \\
\text { Expenditure } \\
\end{array}$ & WCY & Government Consumption Expenditure & $\begin{array}{c}\text { US\$ } \\
\text { billions }\end{array}$ & 0.97 & \\
\hline & $\begin{array}{l}\text { Household Consumption } \\
\text { Expenditure }\end{array}$ & WCY & Household Consumption Expenditure & $\begin{array}{c}\text { US\$ } \\
\text { billions }\end{array}$ & 0.97 & \\
\hline \multirow{5}{*}{$\begin{array}{c}\text { Governance } \\
\text { Infrastructure }\end{array}$} & $\begin{array}{l}\text { Political Stability and } \\
\text { Absence of } \\
\text { Violence/Terrorism }\end{array}$ & WGI & $\begin{array}{l}\text { Perception of the likelihood that the } \\
\text { government will be destabilized or } \\
\text { overthrown by unconstitutional or violent } \\
\text { means, including politically-motivated } \\
\text { violence and terrorism. }\end{array}$ & $-2.5 / 2.5$ & 0.88 & \multirow{5}{*}{0.97} \\
\hline & $\begin{array}{l}\text { Government } \\
\text { Effectiveness }\end{array}$ & WGI & $\begin{array}{l}\text { Perception of the quality of public services, } \\
\text { the quality of the civil service and the degree } \\
\text { of its independence from political pressures, } \\
\text { the quality of policy formulation and } \\
\text { implementation, and the credibility of the } \\
\text { government's commitment to such policies. }\end{array}$ & $-2.5 / 2.5$ & 0.86 & \\
\hline & Regulatory Quality & WGI & $\begin{array}{l}\text { Perception of the ability of the government to } \\
\text { formulate and implement sound policies and } \\
\text { regulations that permit and promote private } \\
\text { sector development. }\end{array}$ & $-2.5 / 2.5$ & 0.90 & \\
\hline & Rule of Law & WGI & $\begin{array}{l}\text { Perceptions of the extent to which agents have } \\
\text { confidence in and abide by the rules of } \\
\text { society, and in particular the quality of } \\
\text { contract enforcement, property rights, the } \\
\text { police, and the courts, as well as the } \\
\text { likelihood of crime and violence. }\end{array}$ & $-2.5 / 2.5$ & 0.89 & \\
\hline & Control of Corruption & WGI & $\begin{array}{l}\text { Perceptions of the extent to which public } \\
\text { power is exercised for private gain, including } \\
\text { both petty and grand forms of corruption, as } \\
\text { well as "capture" of the state by elites and } \\
\text { private interests. }\end{array}$ & $-2.5 / 2.5$ & 0.85 & \\
\hline
\end{tabular}


Table 6 - Correlation matrix and descriptive statistics of dependent and independent variables (410 observations)

\begin{tabular}{|c|c|c|c|c|c|c|c|c|c|c|c|c|c|c|c|c|c|c|c|c|c|c|c|c|c|}
\hline & Variables & 1 & 2 & 3 & 4 & 5 & 6 & 7 & 8 & 9 & 10 & 11 & 12 & 13 & 14 & 15 & 16 & 17 & 18 & 19 & 20 & 21 & 22 & 23 & 24 \\
\hline 1 & Outsourcing & 1.000 & & & & & & & & & & & & & & & & & & & & & & & \\
\hline 2 & Repeated Captive Experience & -0.385 & 1.000 & & & & & & & & & & & & & & & & & & & & & & \\
\hline 3 & Repeated Outsourcing Experience & 0.295 & -0.025 & 1.000 & & & & & & & & & & & & & & & & & & & & & \\
\hline 4 & Repeated Growing Captive Experience & -0.313 & 0.476 & -0.113 & 1.000 & & & & & & & & & & & & & & & & & & & & \\
\hline 5 & Repeated Growing Outsourcing Experience & 0.321 & -0.121 & 0.655 & -0.057 & 1.000 & & & & & & & & & & & & & & & & & & & \\
\hline 6 & Repeated Non-Growing Captive Experience & -0.268 & 0.883 & 0.033 & 0.010 & -0.105 & 1.000 & & & & & & & & & & & & & & & & & & \\
\hline 7 & Repeated Non-Growing Outsourcing Experience & 0.101 & 0.061 & 0.722 & -0.102 & -0.022 & 0.125 & 1.000 & & & & & & & & & & & & & & & & & \\
\hline 8 & Growth Perspective & -0.104 & -0.014 & -0.066 & 0.331 & 0.152 & -0.191 & -0.230 & 1.000 & & & & & & & & & & & & & & & & \\
\hline 9 & Inertial Entry Fit & -0.018 & 0.146 & -0.083 & 0.013 & -0.003 & 0.157 & -0.109 & -0.016 & 1.000 & & & & & & & & & & & & & & & \\
\hline 10 & Mindful Entry Fit & -0.018 & 0.142 & -0.003 & 0.055 & 0.083 & 0.133 & -0.071 & 0.030 & 0.951 & 1.000 & & & & & & & & & & & & & & \\
\hline 11 & Country-specific experience & -0.076 & 0.101 & 0.105 & 0.212 & 0.094 & -0.001 & 0.050 & 0.200 & -0.094 & -0.086 & 1.000 & & & & & & & & & & & & & \\
\hline 12 & Medium Size & -0.069 & 0.145 & -0.014 & -0.020 & -0.042 & 0.173 & -0.003 & -0.057 & -0.016 & -0.018 & 0.034 & 1.000 & & & & & & & & & & & & \\
\hline 13 & Large Size & 0.173 & -0.162 & 0.239 & -0.061 & 0.176 & -0.152 & 0.181 & 0.080 & -0.013 & -0.009 & 0.106 & -0.639 & 1.000 & & & & & & & & & & & \\
\hline 14 & High Value-Added Functions & -0.027 & 0.107 & -0.098 & -0.015 & -0.140 & 0.126 & 0.010 & -0.036 & 0.084 & 0.084 & 0.048 & 0.108 & -0.140 & 1.000 & & & & & & & & & & \\
\hline 15 & IT Sector & -0.295 & 0.140 & -0.264 & 0.251 & -0.237 & 0.017 & -0.132 & 0.051 & 0.106 & 0.087 & 0.082 & 0.037 & -0.260 & 0.151 & 1.000 & & & & & & & & & \\
\hline 16 & Cultural Distance & -0.049 & 0.090 & 0.054 & 0.040 & -0.044 & 0.084 & 0.088 & -0.060 & -0.045 & -0.010 & -0.130 & 0.116 & -0.087 & -0.010 & -0.001 & 1.000 & & & & & & & & \\
\hline 17 & Governance Infrastructure & -0.283 & 0.198 & -0.026 & 0.027 & -0.075 & 0.215 & 0.047 & -0.246 & 0.120 & 0.128 & -0.319 & -0.090 & -0.141 & 0.032 & 0.069 & -0.196 & 1.000 & & & & & & & \\
\hline 18 & Market Attractiveness & -0.126 & 0.086 & -0.072 & 0.073 & -0.104 & 0.060 & -0.015 & 0.032 & 0.073 & 0.096 & 0.018 & -0.006 & -0.107 & 0.111 & 0.148 & 0.027 & 0.125 & 1.000 & & & & & & \\
\hline 19 & Home country United States & 0.264 & -0.341 & 0.256 & -0.027 & 0.134 & -0.378 & 0.242 & 0.096 & -0.084 & -0.061 & 0.245 & 0.023 & 0.281 & 0.029 & -0.042 & -0.018 & -0.308 & -0.093 & 1.000 & & & & & \\
\hline 20 & Access to Qualified Talents & 0.031 & -0.080 & 0.073 & 0.086 & 0.095 & -0.137 & 0.064 & 0.158 & -0.030 & 0.000 & 0.051 & -0.174 & 0.153 & 0.073 & 0.084 & -0.087 & 0.074 & 0.020 & 0.210 & 1.000 & & & & \\
\hline 21 & Labour Cost & 0.201 & -0.335 & 0.006 & 0.042 & -0.011 & -0.405 & 0.032 & 0.194 & -0.115 & -0.132 & 0.111 & -0.122 & 0.245 & 0.004 & 0.003 & -0.013 & -0.261 & -0.108 & 0.281 & 0.164 & 1.000 & & & \\
\hline 22 & Colocation of Manufacturing & -0.113 & 0.055 & 0.070 & -0.059 & 0.028 & 0.093 & 0.092 & -0.097 & 0.035 & 0.057 & -0.092 & 0.084 & -0.082 & 0.068 & -0.142 & 0.057 & 0.169 & 0.067 & 0.030 & 0.111 & -0.080 & 1.000 & & \\
\hline 23 & Market Penetration & -0.222 & 0.347 & -0.064 & 0.110 & -0.026 & 0.337 & -0.053 & -0.097 & 0.127 & 0.103 & -0.128 & 0.083 & -0.246 & 0.139 & -0.002 & -0.038 & 0.272 & 0.080 & -0.203 & 0.038 & -0.371 & 0.163 & 1.000 & \\
\hline \multirow{5}{*}{24} & Age of the Initiative & -0.159 & 0.087 & -0.203 & -0.217 & -0.162 & 0.215 & -0.104 & -0.292 & 0.084 & 0.049 & -0.212 & 0.169 & -0.119 & 0.069 & -0.100 & 0.091 & 0.202 & -0.049 & -0.244 & -0.062 & -0.188 & 0.191 & 0.172 & 1.000 \\
\hline & Mean & 0.485 & 1.937 & 1.876 & 0.695 & 0.746 & 1.229 & 1.039 & 0.571 & 0.695 & 0.710 & 1.083 & 0.366 & 0.415 & 0.161 & 0.259 & 2.159 & -0.775 & 0.467 & 0.666 & 3.617 & 4.173 & 2.544 & 2.580 & 7.229 \\
\hline & Std. Dev. & 0.500 & 2.820 & 2.302 & 1.317 & 1.436 & 2.474 & 1.657 & 0.496 & 0.238 & 0.242 & 1.446 & 0.482 & 0.493 & 0.368 & 0.438 & 1.171 & 1.035 & 1.189 & 0.472 & 1.296 & 1.082 & 1.483 & 1.463 & 3.750 \\
\hline & Min & 0.000 & 0.000 & 0.000 & 0.000 & 0.000 & 0.000 & 0.000 & 0.000 & 0.003 & 0.031 & 0.000 & 0.000 & 0.000 & 0.000 & 0.000 & 0.020 & -2.121 & -0.685 & 0.000 & 1.000 & 1.000 & 1.000 & 1.000 & 2.000 \\
\hline & Max & 1.000 & 19.000 & 14.000 & 7.000 & 10.000 & 19.000 & 7.000 & 1.000 & 1.000 & 1.000 & 7.000 & 1.000 & 1.000 & 1.000 & 1.000 & 5.933 & 1.723 & 6.292 & 1.000 & 5.000 & 5.000 & 6.000 & 5.000 & 37.000 \\
\hline
\end{tabular}


Table 7 - Results of step I and II

\begin{tabular}{|c|c|c|c|c|}
\hline \multirow[t]{2}{*}{ Variables } & \multicolumn{2}{|c|}{$\begin{array}{c}\text { Step I } \\
\text { D.V.: Outsourcing }\end{array}$} & \multicolumn{2}{|c|}{$\begin{array}{c}\text { Step II } \\
\text { D.V.: Growth perspective }\end{array}$} \\
\hline & (1.a) & (1.b) & (2.a) & (2.b) \\
\hline Repeated Captive Experience & $\begin{array}{c}-0.167 * * \\
(-3.16)\end{array}$ & & & \\
\hline Repeated Outsourcing Experience & $\begin{array}{c}0.213^{* * *} \\
(5.31)\end{array}$ & & & \\
\hline Repeated Growing Captive Experience & & $\begin{array}{c}-0.305 * * * \\
(-3.73)\end{array}$ & & \\
\hline Repeated Growing Outsourcing Experience & & $\begin{array}{c}0.362 * * * \\
(5.18)\end{array}$ & & \\
\hline Repeated Non-Growing Captive Experience & & $\begin{array}{l}-0.050 \\
(-0.85)\end{array}$ & & \\
\hline Repeated Non-Growing Outsourcing Experience & & $\begin{array}{l}0.112 * \\
(2.23)\end{array}$ & & \\
\hline Inertial Entry Fit & & & $\begin{array}{l}0.321 \\
(1.09)\end{array}$ & \\
\hline Mindful Entry Fit & & & & $\begin{array}{l}0.642 * \\
(2.29)\end{array}$ \\
\hline Outsourcing & & & $\begin{array}{c}-0.814 * * * \\
(-4.85)\end{array}$ & $\begin{array}{c}-0.827 * * * \\
(-4.94)\end{array}$ \\
\hline Controls & & & & \\
\hline Country-specific experience & $\begin{array}{c}-0.286^{* * * *} \\
(-4.49)\end{array}$ & $\begin{array}{c}-0.303 * * * \\
(-4.16)\end{array}$ & $\begin{array}{l}0.029 \\
(0.58)\end{array}$ & $\begin{array}{l}0.033 \\
(0.65)\end{array}$ \\
\hline Medium Size & $\begin{array}{l}-0.415 \dagger \\
(-1.90)\end{array}$ & $\begin{array}{l}-0.470^{*} \\
(-2.24)\end{array}$ & $\begin{array}{l}-0.059 \\
(-0.29)\end{array}$ & $\begin{array}{l}-0.060 \\
(-0.29)\end{array}$ \\
\hline Large Size & $\begin{array}{l}-0.497 * \\
(-2.12)\end{array}$ & $\begin{array}{l}-0.559^{*} \\
(-2.45)\end{array}$ & $\begin{array}{l}-0.078 \\
(-0.38)\end{array}$ & $\begin{array}{l}-0.098 \\
(-0.47)\end{array}$ \\
\hline High Value Added Functions & $\begin{array}{l}0.315 \\
(1.59)\end{array}$ & $\begin{array}{l}0.317 \\
(1.64)\end{array}$ & $\begin{array}{l}-0.084 \\
(-0.44)\end{array}$ & $\begin{array}{l}-0.100 \\
(-0.52)\end{array}$ \\
\hline IT Sector & $\begin{array}{c}-0.851^{* * *} \\
(-3.96)\end{array}$ & $\begin{array}{c}-0.836 * * * \\
(-3.93)\end{array}$ & $\begin{array}{l}-0.279 \\
(-1.59)\end{array}$ & $\begin{array}{l}-0.292 \dagger \\
(-1.65)\end{array}$ \\
\hline Cultural Distance & $\begin{array}{c}-0.191^{* *} \\
(-2.65)\end{array}$ & $\begin{array}{l}-0.165^{*} \\
(-2.32)\end{array}$ & $\begin{array}{l}-0.108 \dagger \\
(-1.75)\end{array}$ & $\begin{array}{c}-0.110 \dagger \\
(-1.78)\end{array}$ \\
\hline Governance Infrastructure & $\begin{array}{c}-0.454 * * * \\
(-5.16)\end{array}$ & $\begin{array}{c}-0.421 * * * \\
(-4.78)\end{array}$ & $\begin{array}{c}-0.382 * * * \\
(-4.79)\end{array}$ & $\begin{array}{c}-0.389^{* * *} \\
(-4.86)\end{array}$ \\
\hline Market Attractiveness & $\begin{array}{l}-0.069 \\
(-0.96)\end{array}$ & $\begin{array}{l}-0.059 \\
(-0.95)\end{array}$ & $\begin{array}{l}0.049 \\
(0.89)\end{array}$ & $\begin{array}{l}0.045 \\
(0.80)\end{array}$ \\
\hline Home country United States & $\begin{array}{l}0.266 \\
(1.31)\end{array}$ & $\begin{array}{l}0.450 * \\
(2.12)\end{array}$ & $\begin{array}{l}-0.144 \\
(-0.84)\end{array}$ & $\begin{array}{l}-0.139 \\
(-0.81)\end{array}$ \\
\hline Access to Qualified Talents & $\begin{array}{l}0.054 \\
(0.93)\end{array}$ & $\begin{array}{l}0.059 \\
(1.01)\end{array}$ & $\begin{array}{c}0.207^{* * *} \\
(3.48)\end{array}$ & $\begin{array}{c}0.206^{* * * *} \\
(3.48)\end{array}$ \\
\hline Labour Cost & $\begin{array}{l}0.061 \\
(0.73)\end{array}$ & $\begin{array}{l}0.119 \\
(1.32)\end{array}$ & $\begin{array}{l}0.171^{*} \\
(2.37)\end{array}$ & $\begin{array}{l}0.181^{*} \\
(2.47)\end{array}$ \\
\hline Colocation of Manufacturing & $\begin{array}{c}-0.136^{* *} \\
(-2.59)\end{array}$ & $\begin{array}{l}-0.137 * \\
(-2.52)\end{array}$ & $\begin{array}{l}-0.035 \\
(-0.70)\end{array}$ & $\begin{array}{l}-0.037 \\
(-0.74)\end{array}$ \\
\hline Market Penetration & $\begin{array}{c}-0.098 \dagger \\
(-1.79)\end{array}$ & $\begin{array}{c}-0.109 \dagger \\
(-1.90)\end{array}$ & $\begin{array}{l}-0.012 \\
(-0.23)\end{array}$ & $\begin{array}{l}-0.012 \\
(-0.22)\end{array}$ \\
\hline Age of the Initiative & $\begin{array}{l}-0.012 \\
(-0.52)\end{array}$ & $\begin{array}{l}-0.028 \\
(-1.01)\end{array}$ & $\begin{array}{c}-0.117 * * * \\
(-4.95)\end{array}$ & $\begin{array}{c}-0.118^{* * *} \\
(-4.98)\end{array}$ \\
\hline Constant & $\begin{array}{l}0.784 \\
(1.58) \\
\end{array}$ & $\begin{array}{l}0.557 \\
(1.08) \\
\end{array}$ & $\begin{array}{l}-0.012 \\
(-0.02) \\
\end{array}$ & $\begin{array}{l}-0.261 \\
(-0.51) \\
\end{array}$ \\
\hline Number of observations & 410 & 410 & 410 & 410 \\
\hline Chi-square & $98.074 * * *$ & $120.195 * * *$ & $84.561 * * *$ & $86.342^{* * * *}$ \\
\hline Pseudo R-square & 0.329 & 0.354 & 0.186 & 0.192 \\
\hline
\end{tabular}


Table 8 - Results of step II: interaction terms and subsamples (DV: Growth perspective)

\begin{tabular}{|c|c|c|c|c|c|c|}
\hline \multirow{2}{*}{ Variables } & \multicolumn{2}{|c|}{ Interaction terms } & \multicolumn{4}{|c|}{ Subsamples } \\
\hline & 1 & 2 & 3 (Outsourcing) & 4 (Captive) & 5 (Outsourcing) & $\begin{array}{c}6 \\
\text { (Captive) }\end{array}$ \\
\hline \multirow[t]{2}{*}{ Inertial Entry Fit } & $1.269^{*}$ & & -0.181 & $1.754^{*}$ & & \\
\hline & $(2.33)$ & & $(-0.26)$ & -2.43 & & \\
\hline \multirow[t]{2}{*}{ Mindful Entry Fit } & & $1.084^{*}$ & & & 0.931 & $2.196^{* *}$ \\
\hline & & $(2.09)$ & & & $(1.60)$ & $(3.16)$ \\
\hline \multirow[t]{2}{*}{ Outsourcing } & 0.251 & -0.348 & & & & \\
\hline & $(0.46)$ & $(-0.70)$ & & & & \\
\hline \multirow[t]{2}{*}{ Outsourcing*Inertial Entry Fit } & $-1.862^{*}$ & & & & & \\
\hline & $(-2.02)$ & & & & & \\
\hline \multirow[t]{2}{*}{ Outsourcing*Mindful Entry Fit } & & -0.810 & & & & \\
\hline & & $(-1.01)$ & & & & \\
\hline \multirow[t]{2}{*}{ Country-specific experience } & -0.032 & 0.007 & -0.048 & -0.037 & 0.035 & -0.059 \\
\hline & $(-0.54)$ & $(0.13)$ & $(-0.53)$ & $(-0.40)$ & $(0.41)$ & $(-0.64)$ \\
\hline \multirow{2}{*}{ Medium Size } & -0.139 & -0.095 & $0.700^{*}$ & $-0.810 * *$ & $0.855^{*}$ & $-0.852^{* *}$ \\
\hline & $(-0.67)$ & $(-0.45)$ & $(2.00)$ & $(-3.02)$ & $(2.43)$ & $(-3.12)$ \\
\hline \multirow[t]{2}{*}{ Large Size } & -0.157 & -0.133 & 0.149 & -0.207 & 0.278 & -0.25 \\
\hline & $(-0.74)$ & $(-0.63)$ & $(0.41)$ & $(-0.68)$ & $(0.76)$ & $(-0.81)$ \\
\hline \multirow[t]{2}{*}{ High Value Added Functions } & -0.032 & -0.080 & -0.134 & 0.07 & -0.238 & 0.068 \\
\hline & $(-0.17)$ & $(-0.41)$ & $(-0.45)$ & $(0.27)$ & $(-0.81)$ & $(0.26)$ \\
\hline \multirow[t]{2}{*}{ IT Sector } & $-0.555^{*}$ & $-0.406 \dagger$ & -0.348 & $-0.680^{*}$ & 0.065 & $-0.772^{*}$ \\
\hline & $(-2.50)$ & $(-1.91)$ & $(-0.79)$ & $(-2.18)$ & $(0.15)$ & $(-2.56)$ \\
\hline \multirow[t]{2}{*}{ Cultural Distance } & $-0.145^{*}$ & $-0.125 \dagger$ & $-0.217 \dagger$ & $-0.142 \dagger$ & -0.171 & $-0.168^{*}$ \\
\hline & $(-2.23)$ & $(-1.94)$ & $(-1.84)$ & $(-1.71)$ & $(-1.44)$ & $(-1.99)$ \\
\hline \multirow[t]{2}{*}{ Governance Infrastructure } & $-0.479 * * *$ & $-0.430 * * *$ & $-0.586^{* * *}$ & $-0.456^{* *}$ & $-0.490^{* * *}$ & $-0.508 * * *$ \\
\hline & $(-4.94)$ & $(-4.71)$ & $(-3.89)$ & $(-3.11)$ & $(-3.38)$ & $(-3.51)$ \\
\hline \multirow[t]{2}{*}{ Market Attractiveness } & 0.041 & 0.041 & 0.231 & -0.007 & $0.271 \dagger$ & -0.011 \\
\hline & $(0.72)$ & $(0.72)$ & $(1.56)$ & $(-0.12)$ & $(1.86)$ & $(-0.19)$ \\
\hline \multirow[t]{2}{*}{ Home country United States } & 0.009 & -0.071 & -0.024 & 0.15 & -0.223 & 0.216 \\
\hline & $(0.05)$ & $(-0.38)$ & $(-0.08)$ & $(0.58)$ & $(-0.76)$ & $(0.84)$ \\
\hline \multirow[t]{2}{*}{ Access to Qualified Talents } & $0.222 * * *$ & $0.211^{* * *}$ & $0.210^{* *}$ & $0.279^{* *}$ & $0.198^{*}$ & $0.273^{* *}$ \\
\hline & $(3.70)$ & $(3.54)$ & $(2.71)$ & $(2.67)$ & $(2.54)$ & $(2.62)$ \\
\hline \multirow[t]{2}{*}{ Labour Cost } & $0.186^{*}$ & $0.187^{*}$ & 0.062 & $0.272 * *$ & 0.071 & $0.303^{* *}$ \\
\hline & $(2.54)$ & $(2.54)$ & $(0.54)$ & $(2.63)$ & $(0.59)$ & $(2.8)$ \\
\hline \multirow[t]{2}{*}{ Colocation of Manufacturing } & -0.061 & -0.047 & -0.024 & $-0.175^{*}$ & -0.007 & $-0.193 *$ \\
\hline & $(-1.17)$ & $(-0.91)$ & $(-0.33)$ & $(-2.05)$ & $(-0.09)$ & $(-2.32)$ \\
\hline \multirow[t]{2}{*}{ Market Penetration } & -0.044 & -0.025 & -0.001 & -0.054 & 0.027 & -0.05 \\
\hline & $(-0.79)$ & $(-0.45)$ & $(-0.01)$ & $(-0.58)$ & $(0.37)$ & $(-0.55)$ \\
\hline \multirow[t]{2}{*}{ Age of the Initiative } & $-0.126^{* * *}$ & $-0.121 * * *$ & $-0.108^{* *}$ & $-0.174 * * *$ & $-0.099 * *$ & $-0.172^{* * *}$ \\
\hline & $(-5.15)$ & $(-5.05)$ & $(-3.03)$ & $(-4.78)$ & $(-2.80)$ & $(-4.83)$ \\
\hline Number of observations & 410 & 410 & 199 & 211 & 199 & 211 \\
\hline Chi-square & 84.305 & 85.788 & 46.520 & 66.560 & 46.858 & 69.721 \\
\hline Pseudo R-square & 0.193 & 0.193 & 0.169 & 0.308 & 0.177 & 0.315 \\
\hline
\end{tabular}




\section{FIGURES}

Figure 1: Representation of the empirical methodology

STEP 1

\begin{tabular}{|c|}
\hline Inertial entry choice model (a) \\
(Equation 1.a) \\
\hline
\end{tabular}

Mindful entry choice model (b)

(Equation 1.b)
Mindful

entry fit
STEP 2

Outcome

(Equation 2.a)
Outcome

(Equation 2.b) 
Figure 2: Interaction terms between outsourcing and inertial (2.a) and mindful (2.b) entry fits

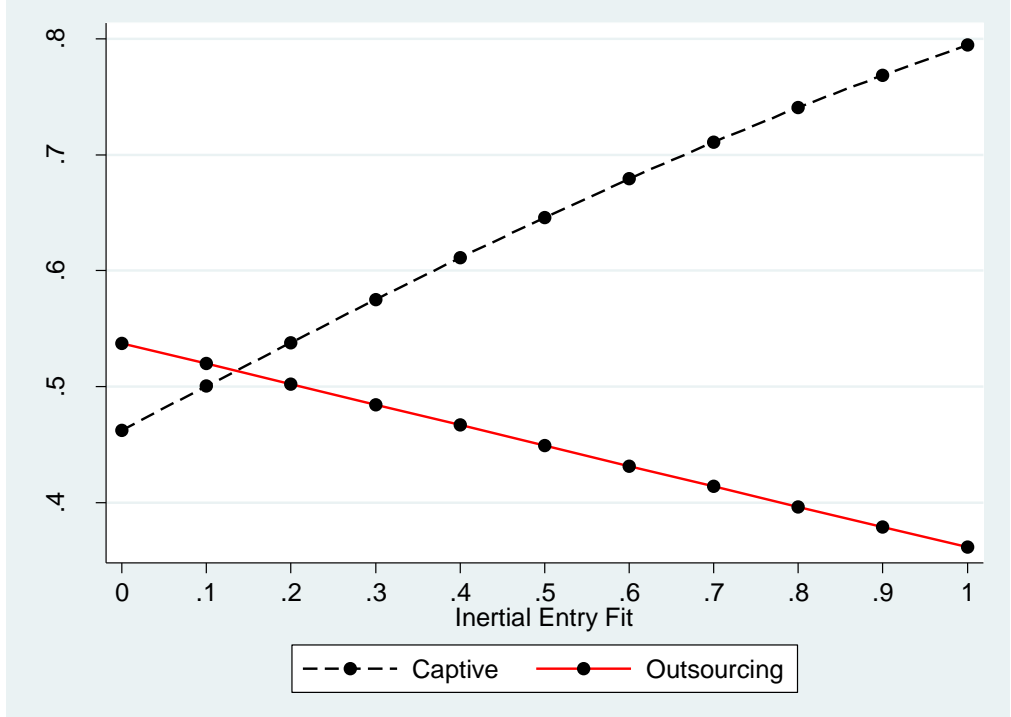

2.a: Interaction term between Inertial Entry Fit and Outsourcing

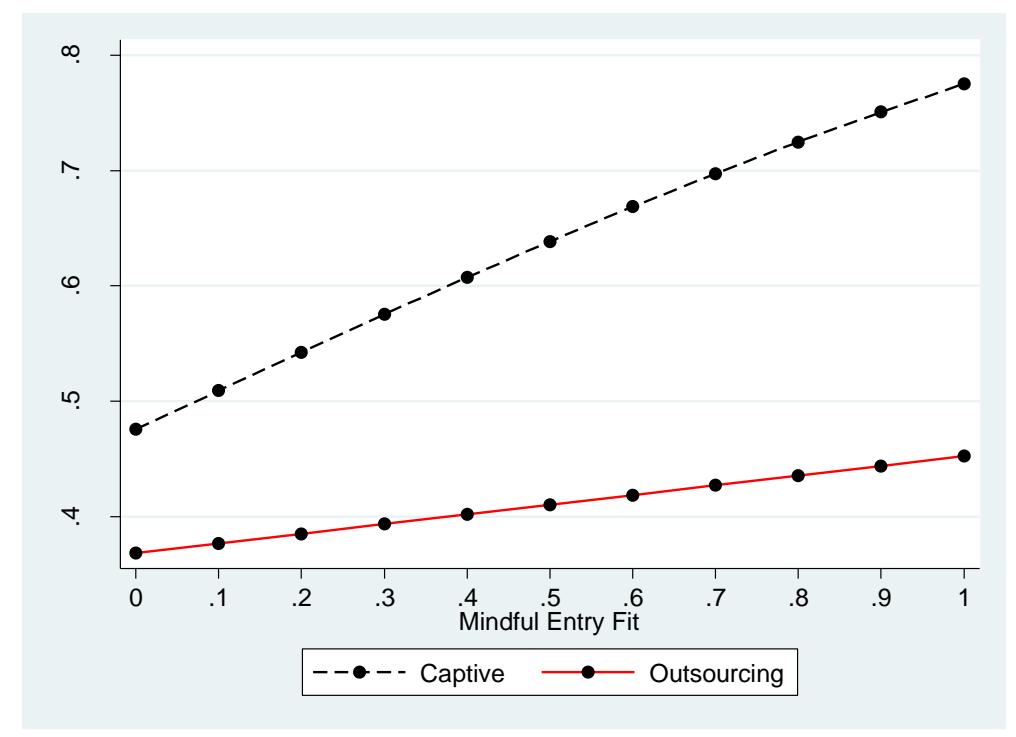

2.b: Interaction term between Mindful Entry Fit and Outsourcing 


\section{APPENDIX}

Table A: Summary of the variables employed in the model

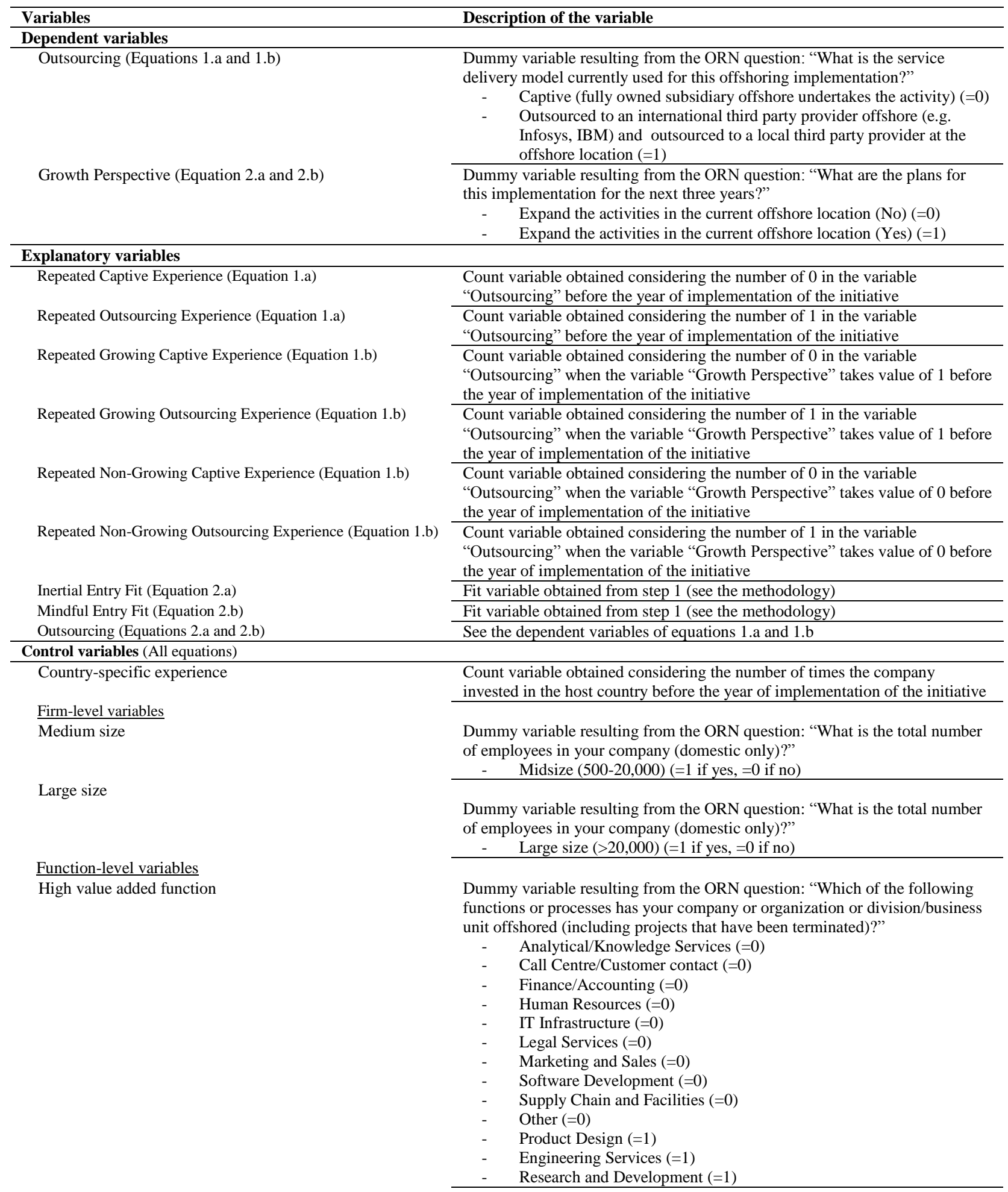

Industry-level variables

Dummy variable resulting from the ORN question: "What is the primary

industry sector of your company?'

- Software and IT services $(=1)$ 
Aerospace and Defence $(=0)$

Arts, Entertainment and Recreation $(=0)$

Automotive $(=0)$

Construction $(=0)$

Energy, Utilities and Mining $(=0)$

Financial Services and Insurance $(=0)$

Government/Public Services $(=0)$

Healthcare $(=0)$

Manufacturing (=0)

Pharmaceuticals and Life Sciences $(=0)$

Professional Services $(=0)$

Retail and Consumer Goods $(=0)$

Telecommunications $(=0)$

- Transportation and Logistics $(=0)$

\section{Country-level variables \\ Cultural Distance}

Governance Infrastructure

Market Attractiveness

Home country United States

\section{Deal-level variables}

Access to Qualified Talent

Labour Cost

Colocation of manufacturing

Market Penetration

Age of the Initiative
Difference between the home and host cultures computed employing the formula adopted by Kogut and Singh (1988) (Hofstede, 2001)

First order construct stemming from an exploratory factor analysis on location variables; see table 5 for further details (WGI database)

First order construct stemming from an exploratory factor analysis on location variables; see table 5 for further details (WGI database)

Dummy variable resulting from the ORN question: "In which country is your company headquarters located?" (see table 1 for further information)

- $\quad$ United States (1)

- $\quad$ Rest of the World (0)

Likert scale variable resulting from the ORN question: "What is the importance of each of the following drivers in considering offshoring this function?"

- $\quad$ Access to qualified personnel offshore (1-'not important' 5-'very important')

Likert scale variable resulting from the ORN question: "What is the importance of each of the following drivers in considering offshoring this function?"

- Labour cost savings (1-'not important' 5-'very important')

Likert scale variable resulting from the ORN question: "Why was this particular location chosen?"

- $\quad$ Co-locating with existing offshore business processes facilities (1-'not important' 5-'very important')

Likert scale variable resulting from the ORN question: "What is the importance of each of the following drivers in considering offshoring this function?"

- $\quad$ Access to new markets for products and services (1-'not important' 5'very important')

Difference between the year of the last release of the survey (2011) and the year of the initiative, the latter resulting from the ORN question: "In what year was this implementation launched?" 